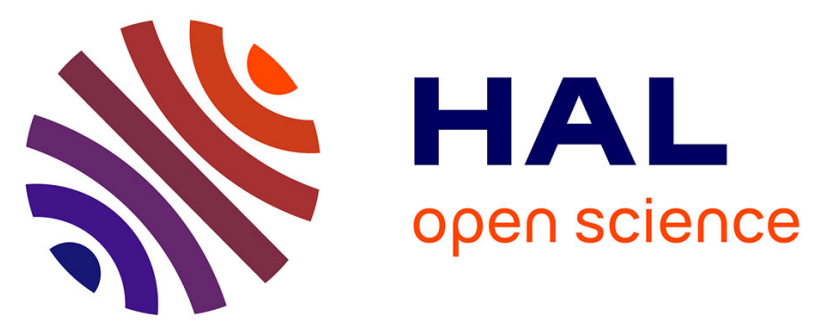

\title{
Aqueous Reduction of [Cp*2W2O5]: Characterization of the Triangular Clusters [Cp*3W3O4(OH)2]2+ and [Cp*3W3O6]+ - Comparison with Molybdenum
}

Chiara Dinoi, Pelin Sözen, Gülnur Taban, Deniz Demir, Funda Demirhan, Petr Prikhodchenko, Jenny Gun, Ovadia Lev, Jean-Claude Daran, Rinaldo Poli

\section{To cite this version:}

Chiara Dinoi, Pelin Sözen, Gülnur Taban, Deniz Demir, Funda Demirhan, et al.. Aqueous Reduction of [Cp*2W2O5]: Characterization of the Triangular Clusters [Cp*3W3O4(OH)2]2+ and [Cp*3W3O6]+ - Comparison with Molybdenum. European Journal of Inorganic Chemistry, 2007, 2007 (27), pp.43064316. 10.1002/ejic.200700419 . hal-03193935

\section{HAL Id: hal-03193935 https://hal.science/hal-03193935}

Submitted on 9 Apr 2021

HAL is a multi-disciplinary open access archive for the deposit and dissemination of scientific research documents, whether they are published or not. The documents may come from teaching and research institutions in France or abroad, or from public or private research centers.
L'archive ouverte pluridisciplinaire HAL, est destinée au dépôt et à la diffusion de documents scientifiques de niveau recherche, publiés ou non, émanant des établissements d'enseignement et de recherche français ou étrangers, des laboratoires publics ou privés. 


\title{
Aqueous reduction of $\left[\mathrm{Cp}_{2}{ }_{2} \mathrm{~W}_{2} \mathrm{O}_{5}\right]$ : characterization of the triangular clusters $\left[\mathrm{Cp}_{3} \mathrm{~W}_{3} \mathrm{O}_{4}(\mathrm{OH})_{2}\right]^{2+}$ and $\left[\mathrm{Cp}_{3}{ }_{3} \mathrm{~W}_{3} \mathrm{O}_{6}\right]^{+}$- Comparison with molybdenum
}

\author{
Chiara Dinoi, ${ }^{[a]}$ Pelin Sözen, ${ }^{[b]}$ Gülnur Taban, ${ }^{[b]}$ Deniz Demir, ${ }^{[b]}$ Funda Demirhan, ${ }^{*[b]}$ Petr \\ Prikhodchenko, ${ }^{[c]}$ Jenny Gun, ${ }^{[c]}$ Ovadia Lev, ${ }^{[c]}$ Jean-Claude Daran ${ }^{[a]}$ and Rinaldo Poli* ${ }^{[a]}$
}

Keywords: Tungsten / Aqueous organometallic chemistry / Oxo ligands / Metal clusters / DFT calculations

Zinc reduction of $\mathrm{Cp}_{2} \mathrm{~W}_{2} \mathrm{O}_{5}$ in an acidified water-methanol medium affords the green 3-electron trinuclear cluster $\left[\mathrm{Cp}^{*}{ }_{3} \mathrm{~W}_{3} \mathrm{O}_{4}(\mathrm{OH})_{2}\right]^{2+}$, isolated and crystallographically characterized as the triflate salt, 1 . Upon exposure to air, this complex is oxidized to a related 2-electron cluster, $\left[\mathrm{Cp}^{*}{ }_{3} \mathrm{~W}_{3} \mathrm{O}_{6}\right]^{+}$, which has been crystallized and characterized in three different salts, 2-4. The 3-electron cluster exhibits a near-tetragonal frozenglass EPR spectrum, with evidence of coupling of the unpaired electron to only one of the three $\mathrm{W}$ atoms. The two-electron cluster is diamagnetic. An electrospray ionization $\mathrm{MS}^{\mathrm{n}}$ study reveals a stepwise expulsion of neutral $\left[\mathrm{Cp} * \mathrm{WO}_{2}\right]$ units as the main fragmentation process. DFT calculations unveil the intimate details of the electronic structure for these complexes and fully rationalize the structural and spectroscopic properties. [a] Laboratoire de Chimie de Coordination, UPR CNRS 8241 liée par convention à l'Université Paul Sabatier et à l'Institut National

Polytechnique de Toulouse, 205 Route de Narbonne, 31077 Toulouse Cedex, France.

Fax: +33-561553003

E-mail: Rinaldo.Poli@1cc-toulouse.fr

[b] Celal Bayar University, Faculty of Sciences \& Liberal Arts, Department of Chemistry, 45030, Muradiye-Manisa, Turkey

[n] Laboratory of Environmental Chemistry, The Casali Institute of Applied Chemistry, The Hebrew University of Jerusalem, Jerusalem 91904, Israel

Supporting information for this article is available on the WWW under http://www.eurjic.org/ or from the author.

\section{Introduction}

Aqueous organometallic chemistry is attracting growing interest because of its "green" impact ${ }^{[1-3]}$ and because of its potential in catalytic ${ }^{[4,5]}$ and biomedical applications ${ }^{[6]}$. Although this area is widely explored for low-valent systems, usually upon appending hydrophilic functionalities to the ligand periphery in order to increase solubility in an aqueous environment ${ }^{[7-9]}$, studies of high oxidation organometallics are still rather scarse. ${ }^{[10-12]}$ For redoxactive metals, these studies are particularly interesting as they may open the way to electrocatalytic applications. ${ }^{[12]}$

In a recent contribution [13], we have reported that the zinc reduction of $\mathrm{Cp}_{2}{ }_{2} \mathrm{Mo}_{2} \mathrm{O}_{5}$ in a strongly acidic $\left(\mathrm{CF}_{3} \mathrm{COOH}\right.$ or $\mathrm{CF}_{3} \mathrm{SO}_{3} \mathrm{H}$ ) mixed $\mathrm{H}_{2} \mathrm{O}-\mathrm{MeOH}$ medium affords the trinuclear mixed-valence $\left(\mathrm{Mo}_{3}{ }^{13+}\right)$ cluster $\left[\mathrm{Cp}_{3}{ }_{3} \mathrm{Mo}_{3} \mathrm{O}_{2}(\mathrm{OH})_{4}\right]^{2+}$. The ion adopts a nearly equilateral triangular shape, each edge being bridged by two ligands. The distortion of the triangle is caused by one edge being bridged by two $\mathrm{OH}$ groups, while the other two edges are bridged by one $\mathrm{O}$ and one $\mathrm{OH}$ group. As a consequence, the former edge is slightly longer than the latter ones. Although the number of bridging $\mathrm{OH}$ vs. $\mathrm{O}$ groups was not revealed directly by the X-ray structural analysis, it was suggested indirectly by the same technique through the existence of short hydrogen-bonding contacts (or lack thereof) between the $\mathrm{Mo}_{3} \mathrm{O}_{6}$ core and the two $\mathrm{CF}_{3} \mathrm{CO}_{2}$ and $\mathrm{CF}_{3} \mathrm{SO}_{3}$ anions, and confirmed by a comparison with a DFT geometry-optimized model, by EPR spectrometry, and by a magnetic susceptibility measurement.

In this contribution, we examine the parallel behaviour of the pentamethylcyclopentadienyltungsten system and report the isolation and characterization of two new, redox-related tritungsten oxo clusters, $\left[\mathrm{Cp}_{3} \mathrm{~W}_{3} \mathrm{O}_{6}\right]^{+}$and $\left[\mathrm{Cp}_{3}{ }_{3} \mathrm{~W}_{3} \mathrm{O}_{4}(\mathrm{OH})_{2}\right]^{2+}$.

\section{Results and Discussion}

(a) The $\left[\mathrm{Cp}_{3} \mathrm{~W}_{3} \mathrm{O}_{4}(\mathrm{OH})_{2}\right]^{2+}$ cluster.

The reduction of $\left[\mathrm{Cp}_{2} \mathrm{~W}_{2} \mathrm{O}_{5}\right]$ was carried out under the same conditions previously used for the reduction of $\left[\mathrm{Cp}_{2}{ }_{2} \mathrm{Mo}_{2} \mathrm{O}_{5}\right]$, namely by metallic zinc in an acidic $\mathrm{H}_{2} \mathrm{O}-\mathrm{MeOH}$ mixed solvent. $\mathrm{MeOH}$ is necessary to increase the solubility of the starting material. The reaction was carried out in the presence of two different acids, trifluoroacetic acid and trifluoromethylsulfonic (triflic) acid. Like for the Mo analogue, a series of color changes was observed over a period of three days, yielding a final green solution through an intermediate orange-red color. Crystallization of the final green product was successful in the case of the triflic acid reaction, revealing the nature of the compound as $\left[\mathrm{Cp}_{3} \mathrm{~W}_{3} \mathrm{O}_{4}(\mathrm{OH})_{2}\right]\left(\mathrm{CF}_{3} \mathrm{SO}_{3}\right)_{2} \cdot 2 \mathrm{H}_{2} \mathrm{O}, \quad$ 1. Thus, the reaction stoichiometry is as shown in equation 1 . The oxidation state of tungsten in the final product is +5 , yielding a 3 -electron $\mathrm{W}_{3}{ }^{15+}$ cluster. Compound $\mathbf{1}$ is quite soluble in $\mathrm{CH}_{2} \mathrm{Cl}_{2}$ and its solutions are air sensitive, turning rapidly to orange when exposed to the atmosphere. The nature of the orange product is shown in the next section.

$$
\begin{aligned}
3\left[\mathrm{Cp}^{*} \mathrm{~W}_{2} \mathrm{O}_{5}\right]+3 \mathrm{Zn}+10 \mathrm{H}^{+} \\
\rightarrow 2\left[\mathrm{Cp}^{*}{ }_{3} \mathrm{~W}_{3} \mathrm{O}_{4}(\mathrm{OH})_{2}\right]^{2+}+3 \mathrm{H}_{2} \mathrm{O}+3 \mathrm{Zn}^{2+}
\end{aligned}
$$

The structure of the dication is shown in Figure 1, whereas Figure 2 illustrates the arrangement of the anions and the interstitial $\mathrm{H}_{2} \mathrm{O}$ molecules relative to the trimetallic cluster. 
Relevant bonding parameters are collected in Table 1 . The $\mathrm{H}$ atoms on the bridging $\mathrm{OH}$ groups could not be directly located from the diffraction data, but their presence is clearly demonstrated by the H-bonding network. Hydrogen bond contacts for compound 1 are available in the Supporting Information. As shown in Figure 2 , the bridging atoms $\mathrm{O} 13$ and $\mathrm{O} 21$ establish short contacts with atoms $\mathrm{O} 100$ and $\mathrm{O} 200$ of the interstitial water molecules. The latter, in turn, establish short contacts with two different atoms of triflate anions: $\mathrm{O} 100$ with $\mathrm{O} 6$ but also with $\mathrm{O} 4$ of a second asymmetric unit; $\mathrm{O} 200$ with $\mathrm{O} 3$ but also with $\mathrm{O} 1$ of a third asymmetric unit. Close inspection of the difference Fourier map obtained after refinement of all heavy atoms revealed in fact the position of the $\mathrm{H}$ atoms on the interstitial $\mathrm{H}_{2} \mathrm{O}$ molecules. This observation excludes the alternative formulation as a neutral $\left[\mathrm{Cp}_{3} \mathrm{~W}_{3} \mathrm{O}_{6}\right]$ complex with two interstitial $\mathrm{CF}_{3} \mathrm{SO}_{3} \mathrm{H}$ molecules, because in the latter case only one of the two $\mathrm{H}_{2} \mathrm{O}$ protons would point toward an oxygen atom of the trifluoromethylsulfonate group while the other one would point toward the bridging oxo group of the $\mathrm{W}_{3}$ cluster. While these considerations establish the presence of $\mathrm{H}$ atoms on $\mathrm{O} 13$ and $\mathrm{O} 21$, they provide no information on the absence or presence of $\mathrm{H}$ atoms on the other bridging $\mathrm{O}$ atoms, $\mathrm{O} 11, \mathrm{O} 12, \mathrm{O} 22$ and $\mathrm{O} 23$. This point will be addressed in further detail later, by inspection of the spectroscopic properties and by comparison of the experimental (X-ray diffraction) and computed (DFT) bonding parameters.

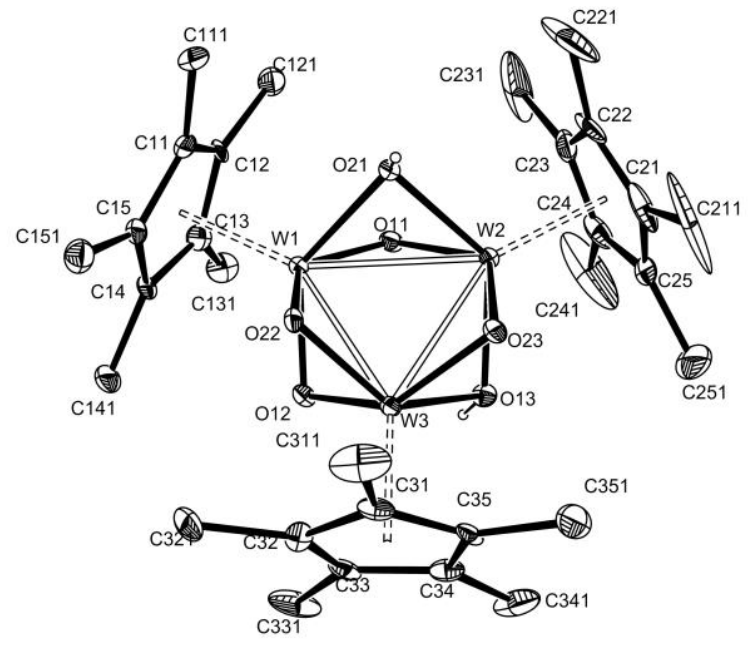

Figure 1. An ORTEP view of the dication in compound $\left[\mathrm{Cp}^{*}{ }_{3} \mathrm{~W}_{3} \mathrm{O}_{4}\right.$ $\left.(\mathrm{OH})_{2}\right]\left(\mathrm{CF}_{3} \mathrm{SO}_{3}\right)_{2} \cdot 2 \mathrm{H}_{2} \mathrm{O}, \mathbf{1}$.

A most informative structural feature is the variation of the W-W distances: the two bonds bridged by one $\mathrm{O}$ and one $\mathrm{OH}$ group, W1W2 (2.7416(3) $⿱$ ) and W2-W3 (2.7485(3) $⿱$ ), are almost $0.1 \AA$ longer than the bond bridged by two O groups, W1-W3 (2.6545(3) $\AA$ ). In addition, the W-OH distances (in the range 2.038-2.080 ̊; average 2.06(2) $\AA$ ) are statistically longer than the W-O distances (in the range 1.872-2.009 $\AA$; average 1.94(6) $\AA$ ). Furthermore, the $\mathrm{W}-(\mu-\mathrm{OH})-\mathrm{W}$ angles $\left(83.39(13)\right.$ and $\left.83.73(13)^{\circ}\right)$ are smaller than the $\mathrm{W}-(\mu-\mathrm{O})-\mathrm{W}$ angles in the $\mathrm{W}(\mu-\mathrm{O})_{2} \mathrm{~W}$ moiety (average $\left.85.54(14)^{\circ}\right)$. The $\mathrm{W}-(\mu-\mathrm{O})-\mathrm{W}$ angles in the $\mathrm{W}(\mu-\mathrm{O})(\mu-\mathrm{OH}) \mathrm{W}$ moiety are even larger (average $\left.90.40(15)^{\circ}\right)$. This is certainly a secondary effect, related to the longer $\mathrm{W}-\mathrm{W}$ distance.

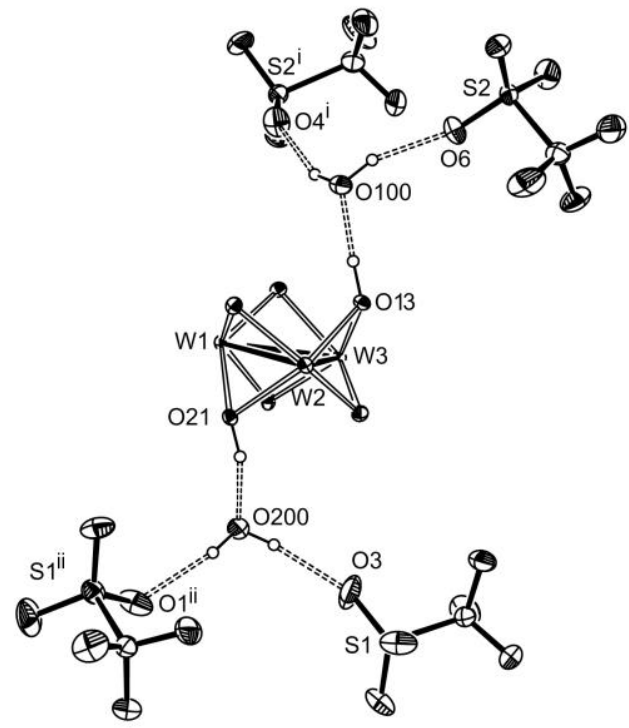

Figure 2. An ORTEP view of compound 1, highlighting the H-bonding interactions between dication, anions, and interstitial water molecules. The $\mathrm{Cp}^{*}$ ligands bonded to the $\mathrm{W}_{3}$ cluster are omitted for clarity [symmetry codes: (i) $3 / 2-x, y-1 / 2,1-z$; (ii) $1 / 2-x, y-1 / 2,-z]$.

Table 1. Selected bond distances $(\AA)$ and angles $\left(^{\circ}\right)$ for the trinuclear clusters in all compounds. ${ }^{[a]}$

\begin{tabular}{lllll} 
(a) Distances & \multicolumn{1}{c}{$\mathbf{1}$} & \multicolumn{1}{c}{$\mathbf{2}^{[\mathrm{b}]}$} & \multicolumn{1}{c}{$\mathbf{3}$} \\
\hline W1-W2 & $2.7416(3)$ & $2.6565(4)$ & $2.6685(5)$ & $2.6637(8)$ \\
W1-W3 & $2.6545(3)$ & $2.6505(5)$ & $2.6657(5)$ & $2.6614(9)$ \\
W2-W3 & $2.7485(3)$ & & $2.6849(5)$ & $2.6606(8)$ \\
W1-O11 & $1.882(4)$ & $1.958(5)$ & $1.980(6)$ & $1.917(8)$ \\
W1-O12 & $1.905(4)$ & $1.975(4)$ & $1.967(6)$ & $1.931(8)$ \\
W1-O21 & $2.076(3)$ & $1.967(4)$ & $1.949(6)$ & $1.958(8)$ \\
W1-O22 & $2.009(3)$ & $1.952(4)$ & $1.955(5)$ & $1.973(8)$ \\
W1-CG1 & $2.034(2)$ & $2.0507(3)$ & $2.054(4)$ & $2.0555(6)$ \\
W2-O11 & $1.979(4)$ & $1.948(5)$ & $1.937(6)$ & $1.935(8)$ \\
W2-O13 & $2.038(4)$ & & $1.968(5)$ & $1.944(8)$ \\
W2-O21 & $2.045(3)$ & $1.960(4)$ & $1.954(5)$ & $1.966(8)$ \\
W2-O23 & $2.001(4)$ & & $1.977(5)$ & $1.967(8)$ \\
W2-CG2 & $2.003(2)$ & $2.0400(4)$ & $2.068(7)$ & $2.0549(6)$ \\
W3-O12 & $2.003(4)$ & & $1.960(6)$ & $1.955(8)$ \\
W3-O13 & $2.080(4)$ & & $1.998(5)$ & $1.936(8)$ \\
W3-O23 & $1.872(3)$ & & $1.962(6)$ & $1.945(8)$ \\
W3-O22 & $1.899(3)$ & & $1.963(6)$ & $1.952(8)$ \\
W3-CG3 & $2.050(2)$ & & $2.053(8)$ & $2.0510(6)$ \\
\hline
\end{tabular}

b) Angles

\begin{tabular}{lllll}
\hline \multicolumn{1}{c}{$\mathbf{1}$} & \multicolumn{1}{c}{$\mathbf{2}^{[\mathrm{b}]}$} & \multicolumn{1}{c}{$\mathbf{3}$} & \multicolumn{1}{c}{$\mathbf{4}$} \\
\hline W2-W1-W3 & $61.216(8)$ & $60.075(7)$ & $60.443(14)$ & $59.95(2)$ \\
W1-W3-W2 & $60.955(7)$ & & $59.828(13)$ & $60.07(2)$ \\
W1-W2-W3 & $57.829(7)$ & $59.843(7)$ & $59.728(13)$ & $59.98(2)$ \\
CG1-W1-O11 & $111.29(11)$ & $113.53(13)$ & $113.2(3)$ & $112.5(2)$ \\
CG1-W1-O12 & $112.01(11)$ & $113.00(13)$ & $112.7(3)$ & $110.3(2)$ \\
CG1-W1-O21 & $114.19(10)$ & $112.67(13)$ & $113.6(3)$ & $115.7(2)$ \\
CG1-W1-O22 & $113.22(10)$ & $112.96(13)$ & $113.2(3)$ & $114.0(2)$ \\
O11-W1-O12 & $93.18(15)$ & $84.6(2)$ & $85.1(2)$ & $87.2(3)$ \\
O11-W1-O22 & $134.61(16)$ & $134.02(18)$ & $133.6(2)$ & $133.4(3)$ \\
O12-W1-O22 & $78.29(14)$ & $76.75(19)$ & $76.8(2)$ & $74.9(3)$ \\
O11-W1-O21 & $73.59(14)$ & $77.6(2)$ & $75.7(2)$ & $76.5(3)$ \\
\hline
\end{tabular}




\begin{tabular}{lllll}
\hline O12-W1-O21 & $133.66(15)$ & $133.80(19)$ & $133.6(2)$ & $134.0(3)$ \\
O22-W1-O21 & $80.67(14)$ & $85.72(19)$ & $86.6(2)$ & $85.8(3)$ \\
CG2-W2-O11 & $114.72(10)$ & $113.40(14)$ & $112.0(3)$ & $114.0(2)$ \\
CG2-W2-O23 & $113.47(10)$ & & $114.0(3)$ & $113.2(2)$ \\
CG2-W2-O13 & $114.14(10)$ & $112.61(13)$ & $111.5(2)$ & $112.9(2)$ \\
CG2-W2-O21 & $115.30(10)$ & & $114.1(2)$ & $113.9(2)$ \\
O11-W2-O23 & $131.80(14)$ & $85.23(19)$ & $133.9(2)$ & $132.8(3)$ \\
O11-W2-O13 & $87.65(15)$ & & $86.2(2)$ & $87.0(3)$ \\
O23-W2-O13 & $72.14(14)$ & $77.16(19)$ & $76.0(2)$ & $75.4(3)$ \\
O11-W2-O21 & $72.32(15)$ & & $76.6(2)$ & $75.9(3)$ \\
O23-W2-O21 & $88.19(14)$ & & $86.2(2)$ & $84.9(3)$ \\
O13-W2-O21 & $130.57(14)$ & $133.2(3)$ & $134.4(2)$ & $133.2(3)$ \\
CG3-W3-O23 & $111.55(11)$ & & $114.9(3)$ & $114.5(2)$ \\
CG3-W3-O22 & $112.91(10)$ & & $112.07(18)$ & $113.7(2)$ \\
CG3-W3-O12 & $112.40(10)$ & & $111.4(3)$ & $111.6(2)$ \\
CG3-W3-O13 & $113.53(10)$ & & $114.06(18)$ & $111.5(2)$ \\
O23-W3-O22 & $93.60(15)$ & & $86.4(2)$ & $86.6(3)$ \\
O23-W3-O12 & $134.86(15)$ & $134.8(3)$ & $133.7(2)$ & $133.9(3)$ \\
O22-W3-O12 & $78.58(15)$ & & $75.6(2)$ & $75.0(3)$ \\
O23-W3-O13 & $73.76(15)$ & & $76.8(2)$ & $75.9(3)$ \\
O22-W3-O13 & $133.32(15)$ & & $133.7(2)$ & $134.8(3)$ \\
O12-W3-O13 & $79.89(15)$ & & $85.6(2)$ & $87.7(3)$ \\
W1-O11-W2 & $90.44(15)$ & $85.70(18)$ & $86.3(2)$ & $87.5(3)$ \\
W1-O12-W3 & $85.55(14)$ & $85.12(17)$ & $85.9(2)$ & $86.5(3)$ \\
W2-O13-W3 & $83.74(13)$ & $84.91(17)$ & $85.8(2)$ & $86.6(3)$ \\
W2-O21-W1 & $83.39(13)$ & & $85.5(2)$ & $85.5(3)$ \\
W3-O22-W1 & $85.53(14)$ & & $85.9(2)$ & $85.6(3)$ \\
W3-O23-W2 & $90.36(15)$ & & $85.2(2)$ & $85.5(3)$ \\
\hline
\end{tabular}

[a] CGn is the center of gravity of the $\mathrm{Cp}^{*}$ ligand bonded to atom Wn. [b] This structure has a symmetry imposed $\mathrm{C}_{2}$ axis passing through atoms W2 and the midpoint of the $\mathrm{W} 1-\mathrm{W} 1^{\mathrm{i}}$ bond. Numbering scheme correspondence: $\mathrm{W} 3=\mathrm{W} 1^{\mathrm{i}} ; \mathrm{O} 12=\mathrm{O} 22^{\mathrm{i}} ; \mathrm{i}:-\mathrm{x}, \mathrm{y},-\mathrm{z}+3 / 2$.

\section{(b) The $\left[\mathrm{Cp}_{3} \mathrm{~W}_{3} \mathrm{O}_{6}\right]^{+}$cluster.}

\section{b.1 The triflate structure (compound 2)}

As stated above, exposure of solutions of compound $\mathbf{1}$ to air rapidly yields orange-red solutions. Crystallization from such oxidized solution yielded red crystals of compound 2 , shown by an $\mathrm{X}$-ray analysis to correspond to $\left[\mathrm{Cp}^{*} \mathrm{~W}_{3} \mathrm{O}_{6}\right]\left(\mathrm{CF}_{3} \mathrm{SO}_{3}\right)$. This formulation is consistent with the spectroscopic properties and with a comparison between the experimental (X-ray diffraction) and computed (DFT) structural parameters, as shown in a later section. The cation is a mixed-valence $\mathrm{W}_{3} \mathrm{~V}, \mathrm{~V}, \mathrm{VI}$ cluster, namely a 2-electron cluster. Thus, the transformation generating this cluster can be described as in equation 2 .

$$
\begin{aligned}
& {\left[\mathrm{Cp}_{3} \mathrm{~W}_{3} \mathrm{O}_{4}(\mathrm{OH})_{2}\right]^{2+}+[\mathrm{ox}] } \\
& \rightarrow\left[\mathrm{Cp}_{3} \mathrm{~W}_{3} \mathrm{O}_{6}\right]^{+}+2 \mathrm{H}^{+}+[\mathrm{red}]
\end{aligned}
$$

Like compound 1, compound $\mathbf{2}$ is soluble in $\mathrm{CH}_{2} \mathrm{Cl}_{2}$, but is also fairly soluble in $\mathrm{MeOH}-\mathrm{H}_{2} \mathrm{O}$ solvent mixtures. These solutions are relatively stable in air, but not indefinitely so, to ultimately yield colorless solutions, apparently faster at high $\mathrm{pH}$. An ${ }^{1} \mathrm{H}$ NMR monitoring in MeOD- ${ }_{2} \mathrm{O}$ reveals the formation of a single resonance $(\delta 2.05)$, attributed to $\left[\mathrm{Cp}^{*} \mathrm{WO}_{3}\right]^{-},{ }^{[14]}$ at neutral or basic $\mathrm{pH}$, whereas several other products, yet to be identified, are obtained under strongly acidic conditions $(\mathrm{pH} 2$ : resonances at $\delta=$ $2.22,2.19,2.15)$.
The structure of $\mathbf{2}$ contains a simple anion and no interstitial solvent molecule, thus firmly establishing the +1 charge of the cluster. However, the cation exhibits a symmetry imposed disorder, because of a twofold axis which passes through atom W2 and through the midpoint of the $\mathrm{W} 1-\mathrm{W} 1^{\mathrm{i}}$ bond. Therefore, there is a 50:50 distribution of two symmetry related orientations of the $\mathrm{Cp}^{*}$ ligand bonded to atom W2. In addition, the triflate anion is also located on a special position (another $\mathrm{C}_{2}$ axis, orthogonally cutting through the C-S bond), yielding again a 50:50 distribution of two symmetry related orientations. In spite of this problem, the structural model refined to quite acceptable final residuals yielding relatively precise bond distances and angles.

The crucial question concerns the absence of $\mathrm{H}$ atoms on the bridging $\mathrm{O}$ atoms. No residual electron density that could be assigned to such atoms was visible from the final difference Fourier map. However, even more convincing is the absence of close contacts between the two ions. The anion is located on the same plane as the $\mathrm{W}_{3}$ triangle, separated from it by one of the $\mathrm{Cp}^{*}$ ligands, see Figure 3. Two of the $\mathrm{Cp}^{*}$ methyl $\mathrm{H}$ atoms are in close contact with the anion: $\mathrm{H} 11 \mathrm{~B} \cdots \mathrm{O} 2,2.448$; $\mathrm{H} 11 \mathrm{~B} \cdots \mathrm{F} 11,2.506$; $\mathrm{H} 12 \mathrm{C} \cdots \mathrm{O} 11,2.428 ; \mathrm{H} 12 \mathrm{C} \cdots \mathrm{F} 12,2.540 \AA$. It may be reasonably argued that, if any $\mathrm{OH}$ group was present on the triangular $\mathrm{W}_{3}$ cluster, this would establish H-bonding contacts with the triflate anion, as observed for the reduced analogue $\mathbf{1}$ (see above). Rather, the space above and below the $\mathrm{W}_{3}$ triangle, in close contact with the bridging $\mathrm{O}$ atoms, is occupied by $\mathrm{CH}_{3}$ groups of $\left[\mathrm{Cp}_{3} \mathrm{~W}_{3} \mathrm{O}_{6}\right]^{+}$ ions located in other asymmetric units.

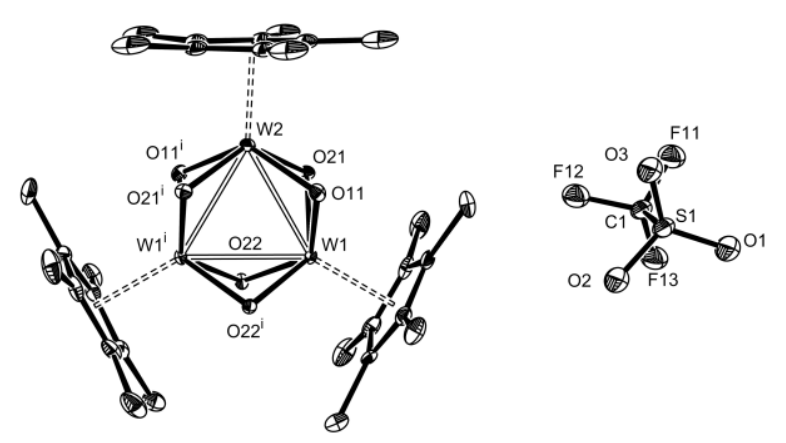

Figure 3. A view of the relative orientation of cation and anion in the structure of $\left[\mathrm{Cp}_{3}^{*} \mathrm{~W}_{3} \mathrm{O}_{6}\right]\left(\mathrm{CF}_{3} \mathrm{SO}_{3}\right), 2$. Only one of the two symmetryrelated orientations of the trifluoromethylsulfonate anion and of the $\mathrm{Cp}^{*}(2)$ ligand are shown for the sake of clarity.

\section{b.2 Two trifluoroacetate structures (compounds $\mathbf{3}$ and $\mathbf{4}$ )}

Before discussing the structural parameters within the $\left[\mathrm{Cp}_{3} \mathrm{~W}_{3} \mathrm{O}_{6}\right]^{+}$ion in more detail, we introduce two additional compounds, related to 2 . These were obtained from the same synthetic procedure shown above, but using $\mathrm{CF}_{3} \mathrm{COOH}$ in place of triflic acid. Although the green product could not be obtained in single crystalline form, red crystals of the oxidation product were obtained after exposure to air. From two batches, crystallized under slightly different conditions, two different crystals containing the same $\left[\mathrm{Cp}^{*} \mathrm{~W}_{3} \mathrm{O}_{6}\right]^{+}$ion were obtained: $\left[\mathrm{Cp}^{*}{ }_{3} \mathrm{~W}_{3} \mathrm{O}_{6}\right]\left[\mathrm{Zn}_{3}\left(\mu_{3}-\mathrm{O}\right)\left(\mu-\mathrm{CF}_{3} \mathrm{COO}\right)_{4}\left(\mathrm{CF}_{3} \mathrm{COO}\right)\left(\mathrm{CF}_{3} \mathrm{COOH}\right)-\right.$ $\left.\left(\mathrm{H}_{2} \mathrm{O}\right)_{3}\right] \cdot \mathrm{CF}_{3} \mathrm{COOH}, \quad 3$, and $\left[\mathrm{Cp}_{3} \mathrm{~W}_{3} \mathrm{O}_{6}\right]_{2}\left[\mathrm{Zn}\left(\mathrm{H}_{2} \mathrm{O}\right)_{6}\right]\left(\mathrm{CF}_{3} \mathrm{COO}\right)_{2}-$ $\left(\mathrm{CF}_{3} \mathrm{COOHOOCCF}\right)_{2} \cdot 4 \mathrm{H}_{2} \mathrm{O}, 4$. The bonding parameters for the tritungsten cluster of each compound are collected in Table 1, together with those of compounds $\mathbf{1}$ and $\mathbf{2}$. 
Compound 3 contains a complex, apparently unprecedented trinuclear zinc anion, as well as an interstitial $\mathrm{CF}_{3} \mathrm{COOH}$ molecule, shown in Figure 4. The closest relatives appear to be $\mathrm{Zn}_{3}\left(\mu_{3}-\mathrm{O}\right)(\mu-$ $\left.\mathrm{CF}_{3} \mathrm{COO}\right)_{\mathrm{x}}$ clusters with $\mathrm{x}=5^{[15]}$ or $6^{[16]}$, with similar frameworks and geometries. The anion in compound 3 contains one 4coordinate $(\mathrm{Zn} 2)$ and two 6-coordinate $(\mathrm{Zn} 1, \mathrm{Zn} 3)$ zinc ions, joined together by a triply bridging ligand, $\mathrm{O}(4)$. One carboxylate ligand bridges atoms $\mathrm{Zn} 1$ and $\mathrm{Zn} 2$, a second one bridges atoms $\mathrm{Zn} 2$ and $\mathrm{Zn} 3$, two additional ones bridge atoms $\mathrm{Zn} 2$ and $\mathrm{Zn} 3$, and a fifth one is terminally bonded to the 4-coordinate $\mathrm{Zn} 2$ atom. The latter one is disordered among two different positions, one of which features a $\mathrm{H}$-bond to the aqua ligand identified by atom $\mathrm{O} 2$ $(\mathrm{O} 71 \mathrm{a} \cdots \mathrm{O} 2=2.70(2) \AA)$. The other position features two weaker $\mathrm{H}$-bonding interactions, the first one with the same aqua ligand $(\mathrm{O} 71 \cdots \mathrm{O} 2=3.11(3) \AA)$ and the second one (not shown in Figure 4) with atom $\mathrm{O} 92$ of a coordinated acid ligand $(\mathrm{O} 71 \cdots \mathrm{O} 92=3.02(2)$ $\AA$ ). The latter ligand is terminally bonded to atom $\mathrm{Zn} 3$ via the carbonyl oxygen atom $\mathrm{O} 91$, while the $\mathrm{OH}$ function of this ligand (O92) is engaged as a proton donor in H-bonding with the triply bridging oxygen atom $\mathrm{O} 4$. The most relevant H-bonding contacts in compound $\mathbf{3}$ are supplied in the Supporting Information. The coordination sphere of 6-coordinate $\mathrm{Zn} 1$ is completed by two water molecules (O1 and $\mathrm{O} 2)$, whereas that of 6-coordinate $\mathrm{Zn} 3$ is completed by a third water molecule $(\mathrm{O} 3)$. The interstitial acid is a proton donor to the $\mathrm{OH}$ group of the coordinated acid (O92) and an acceptor from one of the aqua ligands (O2). The anion also establishes $\mathrm{H}$-bonding interactions, as a proton donor, with the $\mathrm{W}_{3}$ cation: three stronger ones via the aqua ligands $\mathrm{O} 1$ and $\mathrm{O} 3$ (with atoms $\mathrm{O} 21, \mathrm{O} 23$ and $\mathrm{O}^{3}{ }^{\mathrm{i}}$ ), plus two weaker ones via the aqua ligands $\mathrm{O} 3$ (with atom $\mathrm{O} 12^{\mathrm{i}}$ ) and $\mathrm{O} 2$ (with atom $\mathrm{O} 22$ ), see Figure 5 $\mathrm{H}$-bonding interactions are established on both opposite sides of the triangular $\mathrm{W}_{3}$ face, resulting in zig-zag $1 \mathrm{D}$ H-bonded chains (see supplemental figure S1). The most significant bonding parameters of the $\left[\mathrm{Zn}_{3}\left(\mu_{3}-\mathrm{O}\right)\left(\mu-\mathrm{CF}_{3} \mathrm{COO}\right)_{4}\left(\mathrm{CF}_{3} \mathrm{COO}\right)-\right.$ $\left.\left(\mathrm{CF}_{3} \mathrm{COOH}\right)\left(\mathrm{H}_{2} \mathrm{O}\right)_{3}\right]^{-}$anion are collected in Table 2.

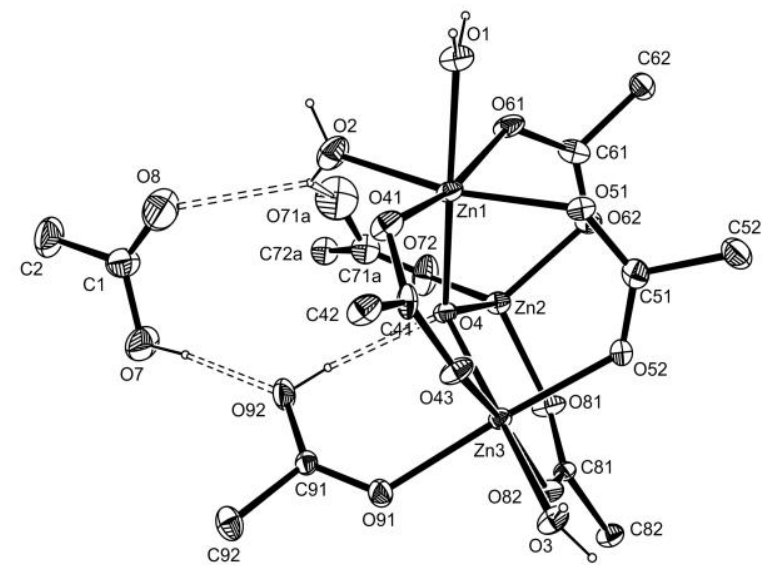

Figure 4. A view of the $\left[\mathrm{Zn}_{3}\left(\mu_{3}-\mathrm{O}\right)\left(\mu-\mathrm{CF}_{3} \mathrm{COO}\right)_{4}\left(\mathrm{CF}_{3} \mathrm{COO}\right)\right.$ $\left.\left(\mathrm{CF}_{3} \mathrm{COOH}\right)\left(\mathrm{H}_{2} \mathrm{O}\right)_{3}\right]^{-}$anion and the interstitial $\mathrm{CF}_{3} \mathrm{COOH}$ molecule in compound 3. Only one component (C71a, C72a and O71a) of the disordered $\mathrm{CF}_{3} \mathrm{COO}$ group is shown for the sake of clarity.

Compound 4 features a $\left[\mathrm{Zn}\left(\mathrm{H}_{2} \mathrm{O}\right)_{6}\right]^{2+}$ ion sitting on an inversion center, plus an isolated $\mathrm{CF}_{3} \mathrm{COO}^{-}$ion, a homoconjugate $\mathrm{CF}_{3} \mathrm{COO} \cdots \mathrm{H}^{\cdots} \mathrm{OOCCF}_{3}-$ ion, and two water molecules in general positions, in addition to the $\left[\mathrm{Cp}^{*} \mathrm{~W}_{3} \mathrm{O}_{6}\right]^{+}$ion, also located in a general position. The three bridging $\mathrm{O}$ atoms on one face of the $\mathrm{W}_{3}$ triangle $(\mathrm{O} 21, \mathrm{O} 22$ and $\mathrm{O} 23)$ are acceptors for H-bonds with the aqua ligands of the $\left[\mathrm{Zn}\left(\mathrm{H}_{2} \mathrm{O}\right)_{6}\right]^{2+}$ cation, see Figure 6. The opposite face of the $\mathrm{W}_{3}$ triangle (atoms $\mathrm{O} 11, \mathrm{O} 12$ and O13) does not establish H-bonds. In addition, the aqua ligands of the $\left[\mathrm{Zn}\left(\mathrm{H}_{2} \mathrm{O}\right)_{6}\right]^{2+}$ cation are H-bond donors toward the interstitial water molecules $\left(\mathrm{O} 111^{\mathrm{i}}\right.$ to $\mathrm{O} 2 \mathrm{~W}$ and $\mathrm{O}_{113^{\mathrm{i}}}$ to $\left.\mathrm{O} 1 \mathrm{~W}\right)$ and to the free $\mathrm{CF}_{3} \mathrm{COO}^{-}$ion $(\mathrm{O} 112$ to $\mathrm{O} 51)$. The other $\mathrm{O}$ atom of the latter (O52) is a $\mathrm{H}$-bond acceptor from $\mathrm{O} 1 \mathrm{~W}$. The homoconjugate anion, $\mathrm{CF}_{3} \mathrm{COOHOOCCF}_{3}{ }^{-}$, also establishes $\mathrm{H}$-bonds as acceptor with both interstitial water molecules. The relevant H-bonding parameters are provided in the Supporting Information. The $\mathrm{H}-$ bonding network yields an arrangement of the structure in 2D layers (see supplemental figure S2).

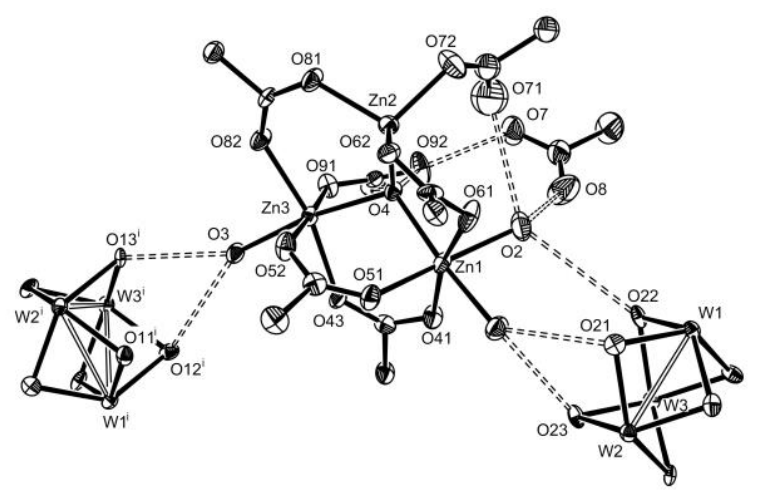

Figure 5. A view of the arrangement between the $\left[\mathrm{Zn}_{3}\left(\mu_{3}-\mathrm{O}\right)(\mu-\right.$ $\left.\left.\mathrm{CF}_{3} \mathrm{COO}\right)_{4}\left(\mathrm{CF}_{3} \mathrm{COO}\right)\left(\mathrm{CF}_{3} \mathrm{COOH}\right)\left(\mathrm{H}_{2} \mathrm{O}\right)_{3}\right]^{-}$anion, the interstitial $\mathrm{CF}_{3} \mathrm{COOH}$ molecule, and the $\left[\mathrm{Cp}_{3}{ }_{3} \mathrm{~W}_{3} \mathrm{O}_{6}\right]^{+}$cation in compound 3. The cation $\mathrm{Cp}^{*}$ ligands and the aqua $\mathrm{H}$ atoms have been removed and only the coordination spheres of the $\mathrm{Zn}$ atoms are shown for clarity [Symmetry code: (i) $1 / 2+\mathrm{X}$, 3/2-y, z-1/2].

Table 2. Relevant bond distances $(\AA)$ and angles $\left(^{\circ}\right)$ for the $\left[\mathrm{Zn}_{3}\left(\mu_{3}-\mathrm{O}\right)(\mu-\right.$ $\left.\left.\mathrm{CF}_{3} \mathrm{COO}\right)_{4}\left(\mathrm{CF}_{3} \mathrm{COO}\right)\left(\mathrm{CF}_{3} \mathrm{COOH}\right)\left(\mathrm{H}_{2} \mathrm{O}\right)_{3}\right]^{-}$anion of compound 3 .

(a) Distances

$\begin{array}{llll}\mathrm{Zn}(1)-\mathrm{O}(1) & 2.047(6) & \mathrm{Zn}(2)-\mathrm{O}(81) & 1.966(7) \\ \mathrm{Zn}(1)-\mathrm{O}(41) & 2.050(6) & \mathrm{Zn}(2)-\mathrm{O}(62) & 1.970(6) \\ \mathrm{Zn}(1)-\mathrm{O}(51) & 2.065(7) & \mathrm{Zn}(3)-\mathrm{O}(3) & 2.068(6) \\ \mathrm{Zn}(1)-\mathrm{O}(4) & 2.076(6) & \mathrm{Zn}(3)-\mathrm{O}(52) & 2.070(6) \\ \mathrm{Zn}(1)-\mathrm{O}(12) & 2.098(7) & \mathrm{Zn}(3)-\mathrm{O}(4) & 2.092(6) \\ \mathrm{Zn}(1)-\mathrm{O}(61) & 2.229(6) & \mathrm{Zn}(3)-\mathrm{O}(82) & 2.108(6) \\ \mathrm{Zn}(2)-\mathrm{O}(72) & 1.953(7) & \mathrm{Zn}(3)-\mathrm{O}(91) & 2.122(6) \\ \mathrm{Zn}(2)-\mathrm{O}(4) & 1.954(5) & \mathrm{Zn}(3)-\mathrm{O}(43) & 2.132(6)\end{array}$

(b) Angles

$\mathrm{O}(4)-\mathrm{Zn}(1)-\mathrm{O}(1)$

$\mathrm{O}(4)-\mathrm{Zn}(1)-\mathrm{O}(2)$

$172.8(2) \quad \mathrm{O}(4)-\mathrm{Zn}(3)-\mathrm{O}(31)$

170.9(2)

$\mathrm{O}(4)-\mathrm{Zn}(1)-\mathrm{O}(41)$

91.6(3) O(4)-Zn(3)-O(43)

$94.4(2)$

$\mathrm{O}(4)-\mathrm{Zn}(1)-\mathrm{O}(51)$

99.5(2) O(4)-Zn(3)-O(52)

$90.6(2)$

$\mathrm{O}(4)-\mathrm{Zn}(1)-\mathrm{O}(61)$

$93.4(2)$

$\mathrm{O}(4)-\mathrm{Zn}(3)-\mathrm{O}(82)$

$100.6(2)$

$93.7(2)$

$\mathrm{O}(4)-\mathrm{Zn}(3)-\mathrm{O}(91)$

$92.0(2)$

$\mathrm{O}(1)-\mathrm{Zn}(1)-\mathrm{O}(2)$

$85.7(3)$

$\mathrm{O}(3)-\mathrm{Zn}(3)-\mathrm{O}(43)$

$76.6(2)$

$\mathrm{O}(1)-\mathrm{Zn}(1)-\mathrm{O}(41)$

$87.3(3)$

$\mathrm{O}(3)-\mathrm{Zn}(3)-\mathrm{O}(52)$

$88.0(3)$

$\mathrm{O}(3)-\mathrm{Zn}(3)-\mathrm{O}(82)$

$\mathrm{O}(1)-\mathrm{Zn}(1)-\mathrm{O}(61)$

$79.4(3)$

$\mathrm{O}(3)-\mathrm{Zn}(3)-\mathrm{O}(91)$

$\mathrm{O}(2)-\mathrm{Zn}(1)-\mathrm{O}(41)$

$92.8(3)$

$\mathrm{O}(43)-\mathrm{Zn}(3)-\mathrm{O}(52)$

$\mathrm{O}(2)-\mathrm{Zn}(1)-\mathrm{O}(51)$

168.1(3)

$\mathrm{O}(43)-\mathrm{Zn}(3)-\mathrm{O}(82)$

$\mathrm{O}(2)-\mathrm{Zn}(1)-\mathrm{O}(61)$

$84.7(3)$

$\mathrm{O}(43)-\mathrm{Zn}(3)-\mathrm{O}(91)$

$\mathrm{O}(41)-\mathrm{Zn}(1)-\mathrm{O}(51)$

$97.0(3)$

$\mathrm{O}(52)-\mathrm{Zn}(3)-\mathrm{O}(82)$

$\mathrm{O}(41)-\mathrm{Zn}(1)-\mathrm{O}(61)$

166.7(3)

$\mathrm{O}(52)-\mathrm{Zn}(3)-\mathrm{O}(91)$

$89.0(3)$

$88.4(2)$

88.8(3)

94.5(3)

164.8(3)

87.2(3)

$87.7(3)$

176.8(3)

84.2(3) $\quad \mathrm{O}(82)-\mathrm{Zn}(3)-\mathrm{O}(91) \quad 89.9(3)$ 


$\begin{array}{llll}\mathrm{O}(4)-\mathrm{Zn}(2)-\mathrm{O}(62) & 112.7(2) & \mathrm{Zn}(1)-\mathrm{O}(4)-\mathrm{Zn}(2) & 111.2(3) \\ \mathrm{O}(4)-\mathrm{Zn}(2)-\mathrm{O}(72) & 115.0(3) & \mathrm{Zn}(1)-\mathrm{O}(4)-\mathrm{Zn}(3) & 112.1(2) \\ \mathrm{O}(4)-\mathrm{Zn}(2)-\mathrm{O}(81) & 112.3(3) & \mathrm{Zn}(2)-\mathrm{O}(4)-\mathrm{Zn}(3) & 111.0(3) \\ \mathrm{O}(62)-\mathrm{Zn}(2)-\mathrm{O}(72) & 107.4(3) & & \\ \mathrm{O}(62)-\mathrm{Zn}(2)-\mathrm{O}(81) & 103.6(3) & & \\ \mathrm{O}(72)-\mathrm{Zn}(2)-\mathrm{O}(81) & 105.0(3) & \end{array}$

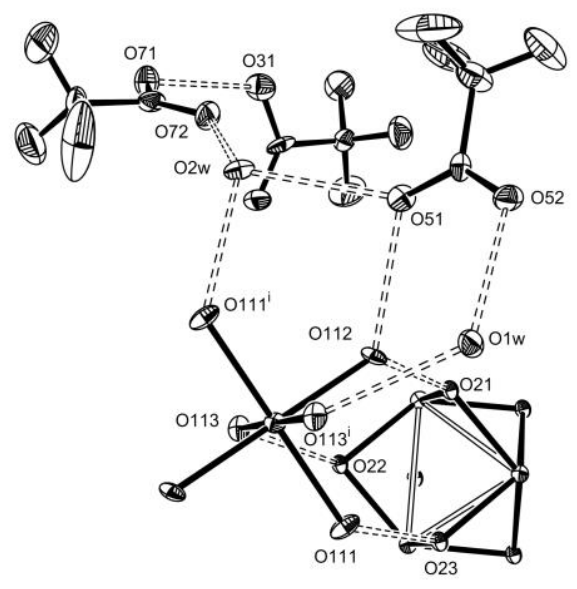

Figure 6. A view of the arrangement between the $\left[\mathrm{Cp}_{3}{ }_{3} \mathrm{~W}_{3} \mathrm{O}_{6}\right]^{+}$, $\left[\mathrm{Zn}\left(\mathrm{H}_{2} \mathrm{O}\right)_{6}\right]^{2+}, \mathrm{CF}_{3} \mathrm{COO}^{-}$, and $\mathrm{CF}_{3} \mathrm{COO} \cdots \mathrm{H}^{\cdots} \mathrm{OOCCF}_{3}^{-}$ions, and the two interstitial $\mathrm{H}_{2} \mathrm{O}$ molecules, in the structure of compound 4. The cation $\mathrm{Cp}^{*}$ ligands and all $\mathrm{H}$ atoms have been removed for clarity [symmetry code: (i) $\mathrm{x},-\mathrm{y},-\mathrm{z}]$.

\section{b.3 Description of the $\left[\mathrm{Cp}^{*}{ }_{3} \mathrm{~W}_{3} \mathrm{O}_{6}\right]^{+}$structure.}

The $\left[\mathrm{Cp}_{3}{ }_{3} \mathrm{~W}_{3} \mathrm{O}_{6}\right]^{+}$cluster has identical bonding parameters, within experimental error, in the structures of compounds $\mathbf{2 , 3}$ and 4, see Table 1. A representative view is shown in Figure 7. On the other hand, these parameters are significantly different from those of the dication of compound $\mathbf{1}$. In particular, the three W-W distances are essentially equivalent, being placed in the narrow range 2.650-2.685 $\AA$, with averages of 2.655(3) $\AA$ for $2,2.673(10)$ $\AA$ for 3 and 2.662(2) $\AA$ for 4, or 2.663(10) $\AA$ for the entire set. This value is very close to the distance of the W-W bond bridged by two $\mathrm{O}$ ligands in compound $\mathbf{1}$. The higher symmetry of the $\mathrm{Cp}_{3}{ }_{3} \mathrm{~W}_{3} \mathrm{O}_{6}$ scaffold in the monocation, approaching ideal $\mathrm{D}_{3 \mathrm{~h}}$ symmetry, is also revealed by the small spread of the W-O distances [range 1.918-1.998 $\AA$; averages 1.960(10) $\AA$ for 2, 1.964(16) $\AA$ for 3, 1.948(17) $\AA$ for 4; global average 1.957(16) $\mathrm{\AA}]$ and W-O-W angles [range 84.9-87.5 $5^{\circ}$ averages $85.2(4)^{\circ}$ for $\mathbf{2}$, $85.8(4)^{\circ}$ for $\mathbf{3}, 86.2(8)^{\circ}$ for $\mathbf{4}$; global average $\left.85.7(7)^{\circ}\right]$. These values are also close to those of the $\mathrm{W}(\mu-\mathrm{O})_{2} \mathrm{~W}$ moiety in compound $\mathbf{1}$.

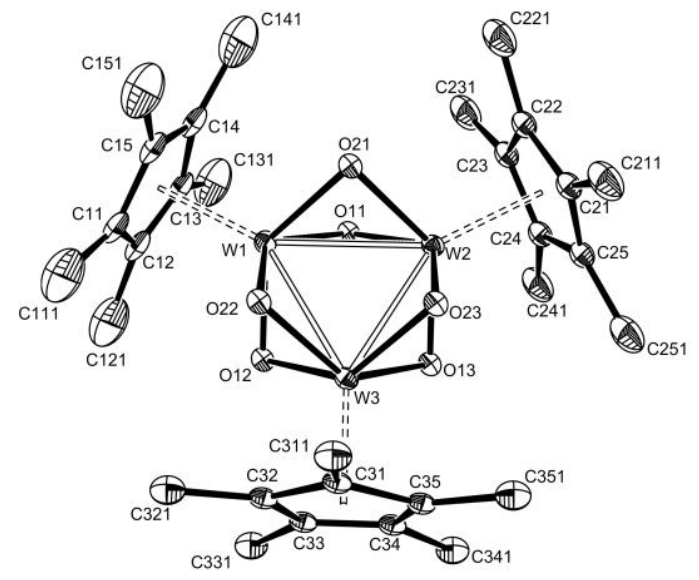

Figure 7. An ORTEP view of the $\left[\mathrm{Cp}_{3}{ }_{3} \mathrm{~W}_{3} \mathrm{O}_{6}\right]^{+}$ion from the structure of compound 3 .

\section{(c) Spectroscopic identification.}

According to the formulation of the two clusters, deriving from the X-ray analyses shown above, as $\left[\mathrm{Cp}_{3}{ }_{3} \mathrm{~W}_{3} \mathrm{O}_{4}(\mathrm{OH})_{2}\right]^{2+}$ for the green derivative and $\left[\mathrm{Cp}_{3}{ }_{3} \mathrm{~W}_{3} \mathrm{O}_{6}\right]^{+}$for the red-orange derivatives, the first cluster has three metal electrons and should therefore be paramagnetic, whereas the second one has only two, which should be located in a symmetric metal-metal bonding combination, ${ }^{[13]}$ and should therefore be diamagnetic. These expectations are in agreement with the experiment.

Compound 1 does not exhibit any strong ${ }^{1} \mathrm{H}$ NMR signal. On the other hand, it has an EPR resonance, although this is clearly visible only at low temperatures $(<200 \mathrm{~K})$. The frozen glass spectrum in $\mathrm{CH}_{2} \mathrm{Cl}_{2}$ solution is shown in Figure 8 . The overall shape is close to that expected for tetragonal symmetry, though a slight splitting of the perpendicular component is clearly visible. This is in nice agreement with the asymmetry of the bridge system, which introduces a slight perturbation to the threefold symmetry of the $\mathrm{W}_{3}$ triangle as also indicated by the $\mathrm{W}-\mathrm{W}$ distances. The perpendicular component does not have sufficient resolution to reveal the ${ }^{183} \mathrm{~W}$ satellites. The parallel component, on the other hand, shows them quite clearly (see enlargement in Figure 8b). This feature was satisfactorily simulated as the sum of three Lorentzians, plus a quadratic function to account for the baseline drift. The satellites correspond to ca. $15 \%$ of the total intensity, in agreement with coupling of the unpaired electron with only one of the three cluster $\mathrm{W}$ atoms (theoretical values of 14.4, 24.7 and $31.6 \%$ are expected for coupling to 1,2 or 3 equivalent $\mathrm{W}$ atoms). This observation will be fully rationalized on the basis of the computational results (vide infra).

Contrary to compound $\mathbf{1}$, compounds $\mathbf{2 - 4}$ do not show any EPR signal. They exhibit instead an NMR resonance at $\delta 2.28$ in $\mathrm{CDCl}_{3}$, consistent with the equivalence of the three $\mathrm{Cp} *$ ligands. Since this single ${ }^{1} \mathrm{H}$ NMR resonance is not conclusively proving the chemical constitution of the isolated bulk material, further characterization was sought by mass spectrometry (MS). 


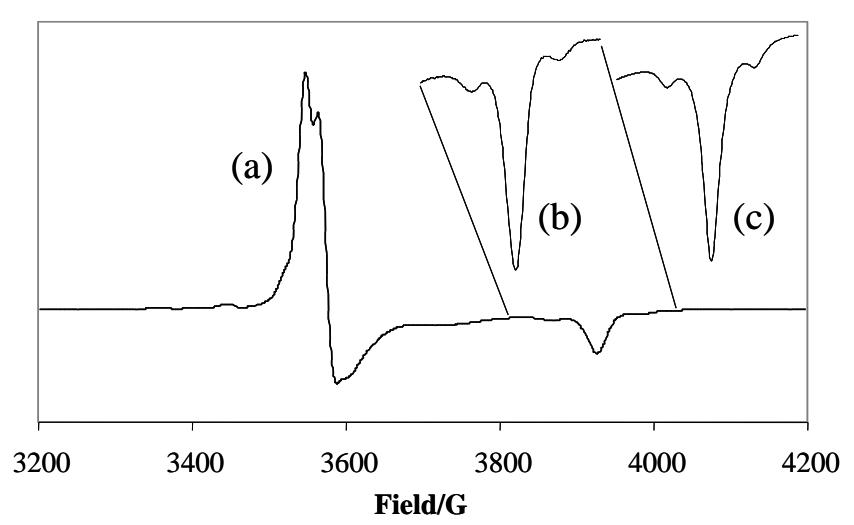

Figure 8. EPR spectrum of a frozen $\mathrm{CH}_{2} \mathrm{Cl}_{2}$ solution of compound $\mathbf{1}$ at $120 \mathrm{~K}$ : (a) experimental spectrum; (b) enlargement of the 3800-4050 G range; (c) simulation of (b), see text.

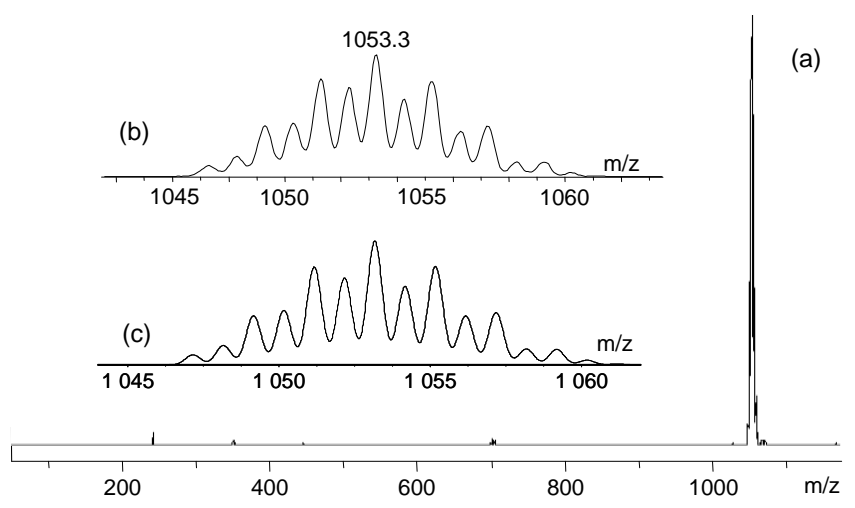

Figure 9. ESI-MS of a $\mathrm{CH}_{2} \mathrm{Cl}_{2}$ solution of compound 4. An expansion of the molecular ion isotopic cluster is shown in part (b) and the theoretical simulation in part (c).
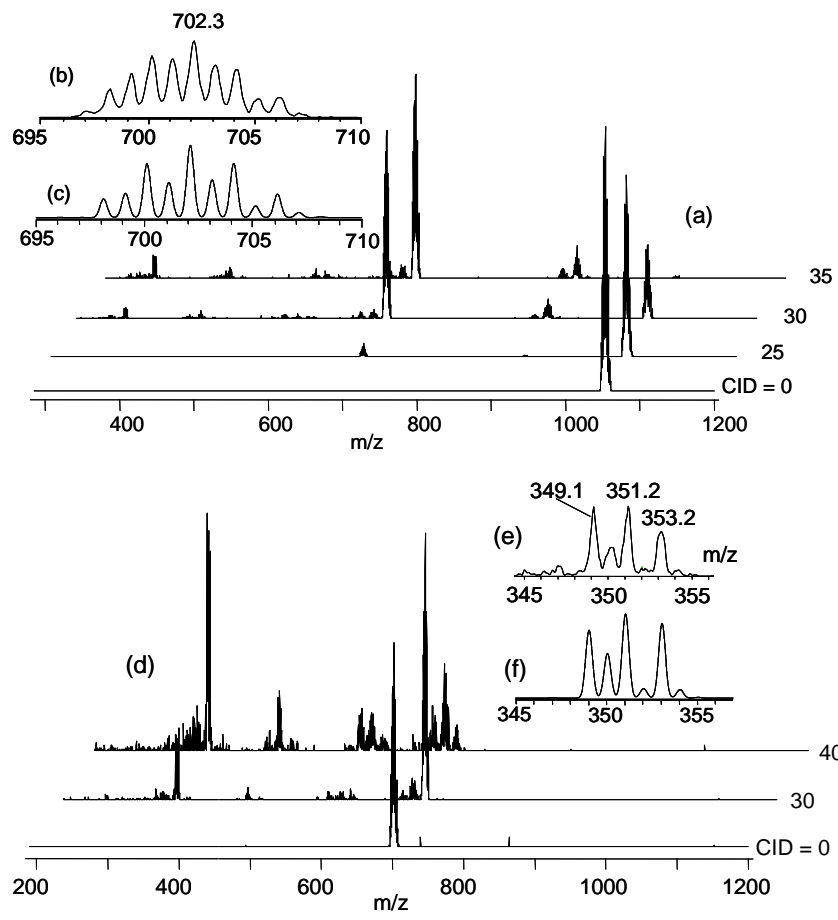

Figure 10. $\mathrm{MS}^{\mathrm{n}}$ studies of the $\left[\mathrm{Cp}_{3}{ }_{3} \mathrm{~W}_{3} \mathrm{O}_{6}\right]^{+}$ion. (a) $\mathrm{MS} / \mathrm{MS}(1053)$ at increasing collision energies, plus expansion (b) and simulation (c) of the product ion. (d) $\mathrm{MS} / \mathrm{MS}(1053) / \mathrm{MS}(702)$ at increasing collision energies, plus expansion (e) and simulation (f) of the product ion.

An electrospray ionisation (ESI) MS study of compound 4 in $\mathrm{CH}_{2} \mathrm{Cl}_{2}$ gives a very clean isotopic cluster, which agrees with the theoretical isotopic distribution of $\left[\mathrm{Cp}^{*}{ }_{3} \mathrm{~W}_{3} \mathrm{O}_{6}\right]^{+}$, see Figure 9. The same pattern is also observed in $\mathrm{MeOH}$ and in $\mathrm{MeOH}-\mathrm{H}_{2} \mathrm{O}$ mixtures. Note the absence of fragmentation peaks, reflecting the robustness of the molecular scaffold. In order to learn about the fragmentation pattern, the collision-induced decay (CID) of this ion was investigated by $\mathrm{MS}^{\mathrm{n}}$. As shown in Figure 10(a), the ion displays a major decay pathway by expulsion of a $\left[\mathrm{Cp} * \mathrm{WO}_{2}\right]$ fragment with transformation into $\left[\mathrm{Cp}^{*} \mathrm{~W}_{2} \mathrm{O}_{4}\right]^{+}$(isotope cluster centered at $\mathrm{m} / \mathrm{z}=702$ ). However, the isotope pattern (Figure 10(b) with simulation in Figure 10(c)), reveals the presence of a second species one mass unit lighter. Therefore, elimination of a $\left[\mathrm{Cp} * \mathrm{WO}_{2} \mathrm{H}\right]$ unit, with the presumed involvement of a $\mathrm{CH}_{3}$ group and generation of a tetramethylfulvene ligand, constitutes a competitive fragmentation pathway. Further trapping of these species and new CID in an MS ${ }^{3}$ experiment, see Figure 10(d), is less selective but the major decay pathway is once again expulsion of a $\left[\mathrm{Cp} * \mathrm{WO}_{2}\right]$ fragment from $\left[\mathrm{Cp}_{2} \mathrm{~W}_{2} \mathrm{O}_{4}\right]^{+}$, yielding $\left[\mathrm{Cp} * \mathrm{WO}_{2}\right]^{+}$ (isotope cluster centered at $\mathrm{m} / \mathrm{z}=351$ ). The latter ion is not produced in a major pathway by direct expulsion of $\left[\mathrm{Cp}_{2}{ }_{2} \mathrm{~W}_{2} \mathrm{O}_{4}\right]$ from the trinuclear species.

\section{(d) DFT calculations}

Model compounds of the triangular $\mathrm{W}_{3}$ clusters, obtained by replacing the $\mathrm{Cp}^{*}$ ligands with the simpler $\mathrm{Cp}$ ring, i.e. $\left[\mathrm{Cp}_{3} \mathrm{~W}_{3} \mathrm{O}_{4}(\mathrm{OH})_{2}\right]^{2+}$ (5) for compound 1 and $\left[\mathrm{Cp}_{3} \mathrm{~W}_{3} \mathrm{O}_{6}\right]^{+}$(6) for compounds $\mathbf{2 - 4}$, were subjected to geometry optimization in order to find further supporting evidence for their stoichiometry (notably the number of $\mathrm{OH}$ vs. $\mathrm{O}$ groups) and to investigate their electronic structure. The calculations were run with no symmetry restrictions. Both calculations converged smoothly, giving final geometries in remarkably good agreement with the corresponding experimental ones for the $\mathrm{Cp}^{*}$ derivatives (see Table 3 ). The only slight discrepancy consists of slightly longer bond lengths from the calculations relative to the experiment (W-O distances by $0.02-$ $0.05 \AA$; W-W distances by $0.06-0.10 \AA$ ), as is typically observed for DFT calculations.

Table 3. Comparison of the DFT optimized geometries (distances in $\AA$, angles in degrees) for the model $\left[\mathrm{Cp}_{3} \mathrm{~W}_{3} \mathrm{O}_{4}(\mathrm{OH})_{2}\right]^{2+}(\mathbf{5})$ and $\left[\mathrm{Cp}_{3} \mathrm{~W}_{3} \mathrm{O}_{6}\right]^{+}(\mathbf{6})$ complexes with the $\mathrm{X}$-ray structures of the $\mathrm{Cp}^{*}$ analogues. ${ }^{[\mathrm{a}]}$

\begin{tabular}{|c|c|c|}
\hline \multirow[t]{2}{*}{ Parameter ${ }^{[b],[c]}$} & \multicolumn{2}{|c|}{$\left[\left(\mathrm{C}_{5} \mathrm{R}_{5}\right)_{3} \mathrm{~W}_{3} \mathrm{O}_{4}(\mathrm{OH})_{2}\right]^{2+}$} \\
\hline & $\mathrm{R}=\mathrm{H}(\mathrm{DFT}), \mathbf{5}$ & $\mathrm{R}=\operatorname{Me}(\mathrm{X} \text {-ray })^{[\mathrm{d}]}$ \\
\hline W-W & 2.723 & $2.6545(3)$ \\
\hline W-W, & $2.839,2.853$ & $2.745(6)$ \\
\hline $\mathrm{W}-(\mu-\mathrm{O})(\mathrm{a})$ & $1.920,1.914$ & $1.902(4)$ \\
\hline $\mathrm{W}-(\mu-\mathrm{O})(\mathrm{b})$ & $2.049,2.054$ & $2.005(4)$ \\
\hline $\mathrm{W}-(\mu-\mathrm{O})(\mathrm{c})$ & $1.894,1.896$ & $1.877(5)$ \\
\hline$W^{\prime}-(\mu-O)(d)$ & $2.012,2.018$ & $1.990(11)$ \\
\hline $\mathrm{W}-(\mu-\mathrm{OH})(\mathrm{e})$ & $2.148,2.152$ & $2.078(4)$ \\
\hline $\mathrm{W}^{\prime}-(\mu-\mathrm{OH})(\mathrm{f})$ & $2.091,2.091$ & $2.042(7)$ \\
\hline W-CG & $2.096,2.099$ & $2.043(14)$ \\
\hline W'-CG' & 2.060 & $2.003(2)$ \\
\hline $\mathrm{W}^{\prime}-\mathrm{W}-\mathrm{W}^{\prime}$ & 57.17 & $57.829(7)$ \\
\hline W-W'-W' & $61.66,61.17$ & $61.08(13)$ \\
\hline $\mathrm{W}-(\mu-\mathrm{O})-\mathrm{W}(\mathrm{a}-\mathrm{b})$ & $86.60,86.60$ & $85.54(14)$ \\
\hline $\mathrm{W}-(\mu-\mathrm{O})-\mathrm{W}^{\prime}(\mathrm{c}-\mathrm{d})$ & $93.16,93.60$ & $90.40(15)$ \\
\hline$W-(\mu-\mathrm{OH})-\mathrm{W}^{\prime}$ (e-f) & $84.09,84.49$ & $83.6(3)$ \\
\hline
\end{tabular}




\begin{tabular}{|c|c|c|c|}
\hline \multicolumn{2}{|c|}{ CG-W-( $\mu-O)$ (a) } & $112.28,113.29$ & $112.5(4)$ \\
\hline \multicolumn{2}{|c|}{ CG-W-( $\mu-O)(b)$} & $113.86,115.23$ & $112.8(4)$ \\
\hline \multicolumn{2}{|c|}{ CG-W-( $\mu-\mathrm{O})(\mathrm{c})$} & $110.54,111.46$ & $111.4(3)$ \\
\hline \multicolumn{2}{|c|}{ CG-W'-( $\mu-O)(d)$} & $113.85,115.97$ & $114.1(12)$ \\
\hline \multicolumn{2}{|c|}{ CG-W-( $\mu-\mathrm{OH})(\mathrm{e})$} & $115.33,116.00$ & $113.9(7)$ \\
\hline \multicolumn{2}{|c|}{$\mathrm{CG}^{\prime}-\mathrm{W}^{\prime}-(\mu-\mathrm{OH})(\mathrm{f})$} & $116.11,116.37$ & $114.7(12)$ \\
\hline \multirow[t]{2}{*}{ Parameter } & \multicolumn{3}{|c|}{$\left[\left(\mathrm{C}_{5} \mathrm{R}_{5}\right)_{3} \mathrm{~W}_{3} \mathrm{O}_{6}\right]^{+}$} \\
\hline & \multicolumn{2}{|c|}{$\mathrm{R}=\mathrm{H}(\mathrm{DFT}), \mathbf{6}$} & $\mathrm{R}=\mathrm{Me}(\mathrm{X} \text {-ray })^{[\mathrm{ee}]}$ \\
\hline \multirow{2}{*}{$\begin{array}{l}\text { W-W } \\
\text { W- }(\mu-O)\end{array}$} & 2.72 & $2,2.717$ & $2.663(10)$ \\
\hline & $\begin{array}{l}1.9 \\
2.0 \\
1.9\end{array}$ & $\begin{array}{l}4,1.932,2.038,1.919 \\
9,2.054,1.918,2.047 \\
7\end{array}$ & $1.957(16)$ \\
\hline W-CG & 2.10 & $9,2.110$ & $2.053(7)$ \\
\hline W-W-W & 59.7 & $1,60.28$ & $60.0(2)$ \\
\hline $\mathrm{W}-(\mu-\mathrm{O})-\mathrm{W}$ & $\begin{array}{l}86 . \\
86.2\end{array}$ & $5,86.63,87.03,87.05$ & $85.7(7)$ \\
\hline CG-W-( $\mu-O)$ & $\begin{array}{l}114 \\
112 \\
113 \\
\end{array}$ & $\begin{array}{l}.05,112.90,114.23 \\
4.42,114.56,112.92 \\
4.48,112.47,113.93\end{array}$ & $113(1)$ \\
\hline
\end{tabular}

${ }^{[a}$ The experimental parameters (X-ray structures) that are chemically and geometrically equivalent are averaged; for the individual parameters, see Table $1 .{ }^{[b]}$ Label $\mathrm{W}$ refers to the two geometrically equivalent $\mathrm{W}$ atoms; $\mathrm{W}$ ' refers to the unique atom sitting on the ideal $\mathrm{C}_{2}$ symmetry axis; $\mathrm{CG}$ and $\mathrm{CG}^{\prime}$ are the centers of gravity of the rings bonded to atoms $\mathrm{W}$ and $\mathrm{W}$ ', respectively. ${ }^{[\mathrm{c}]}$ For the labels assigned to geometrically different $\mathrm{W}-\mathrm{O}$ and W-OH bonds (a-f), refer to Scheme 1. ${ }^{[d]}$ From the structure of compound 1. ${ }^{\left[{ }^{[e]}\right.}$ Averaged values from the structures of compounds 2-4.

The geometrical trends for the less symmetric dihydroxo cluster 5 (see Scheme 1) are perfectly reproduced. Particularly notable is the difference between the $\mathrm{W}-\mathrm{W}$ and $\mathrm{W}-\mathrm{W}$ ' distances. The dioxobridged (W-W) bond is shorter than the two oxohydroxo-bridged (W-W') bonds by about $0.1 \AA$, like in the experimental structure. The lengths of different types of W-O bonds also have the same trend in the calculated and experimental structures $(b>d>a>c$, for the labelling, refer to Scheme 1), as do the different types of W$\mathrm{OH}$ bonds $(\mathrm{e}>\mathrm{f})$. Finally, the two W-CG distances are longer than the W'-CG' distance.

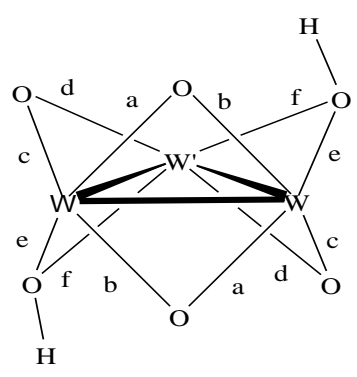

Scheme 1. Labeling of geometrically different W-O bonds in the structure of $\left[\mathrm{Cp}_{3} \mathrm{~W}_{3} \mathrm{O}_{4}(\mathrm{OH})_{2}\right]^{2+}$. The ideal $\mathrm{C}_{2}$ symmetry axis passes through atom $\mathrm{W}^{\prime}$ and through the midpoint of the $\mathrm{W}-\mathrm{W}$ vector. The $\mathrm{Cp}$ ligands are not drawn for the sake of clarity.

Excellent agreement is also found between the optimized geometry for the $\left[\mathrm{Cp}_{3} \mathrm{~W}_{3} \mathrm{O}_{6}\right]^{+}$cluster and the experimentally observed structure for the $\mathrm{Cp}^{*}$ analogue. In particular, the geometry is now close to the ideal $\mathrm{D}_{3 \mathrm{~h}}$ symmetry, with three very similar W-W distances. Note that the average optimized W-W distance in $\mathbf{6}$ is essentially identical to the shorter W-W distance for the dioxo-bridged bond in $\mathbf{5}$. The same phenomenon is observed in the experimental structures. The three W-CG distances are also essentially equivalent.
The electronic structure analysis is particularly interesting. The qualitative interaction diagram for the metal based orbitals in this type of molecular scaffold has been previously discussed ${ }^{[17,18]}$ and is reproduced in Scheme 2 for convenience. The relevant metalbased molecular orbitals calculated for the two systems are shown in Figure 11, whereas more extensive data are available in the Supporting Information. For system 6 - a 2-electron $\mathrm{W}_{3} \mathrm{~V}, \mathrm{~V}, \mathrm{VI}$ cluster - the two metal electrons are located in the $a\left(\mathrm{z}^{2}\right)$ orbital, as expected. This orbital interaction insures the metal-metal attractive force. The additional electron in system 5 - a 3 -electron $\mathrm{W}_{3} \mathrm{~V}, \mathrm{~V}, \mathrm{~V}$ cluster - is located in one of the two orbitals derived from the $e(\mathrm{xy})$ set. Since the ideal symmetry is reduced from $D_{3 h}$ to $C_{2}$ by the addition of the two protons, the $e$ (xy) set splits ( $e_{1}$ of $a$-type $+e_{2}$ of $b$-type) and the unpaired electron is located in the symmetric $a$ component. Note that, whereas the antisymmetric $(b)$ component must be nil on the unique tungsten atom (W') (see Supporting Information), there is no symmetry restriction for the composition of the $a$-type orbital. However, the composition of this orbital is such that the contribution from the two symmetry-equivalent $\mathrm{W}$ atoms is negligible, whereas atom W' contributes greatly. Thus, the spin density is very much localized on the W' atom (0.911), whereas it is negligible on the two $\mathrm{W}$ atoms $(0.028$ and 0.036$)$, in perfect agreement with the measured relative intensity of the satellites in the EPR spectrum (vide supra). In this respect, it should be noted that the related molybdenum complex $\left[\mathrm{Cp}^{*}{ }_{3} \mathrm{Mo}_{3} \mathrm{O}_{2}(\mathrm{OH})_{4}\right]^{2+}$ - a 5-electron $\mathrm{Mo}_{3}{ }^{\mathrm{IV}, \mathrm{IV}, \mathrm{V}}$ cluster - was shown to have the same ordering for the metal-based molecular orbitals. ${ }^{[13]}$ Therefore, the unpaired electron for that complex is located in the antisymmetric $b$ orbital and couples to only two Mo nuclei, again consistent with the experimental evidence from EPR spectroscopy.

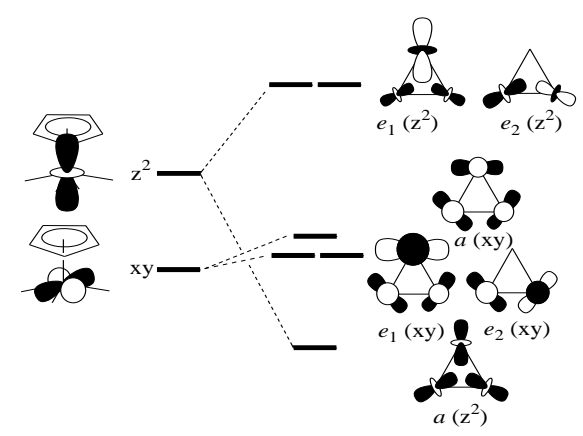

Scheme 2. Qualitative metal-metal orbital interactions for a $\mathrm{Cp}_{3} \mathrm{M}_{3} \mathrm{~L}_{6}$ molecule of ideal $\mathrm{D}_{3 \mathrm{~h}}$ symmetry.

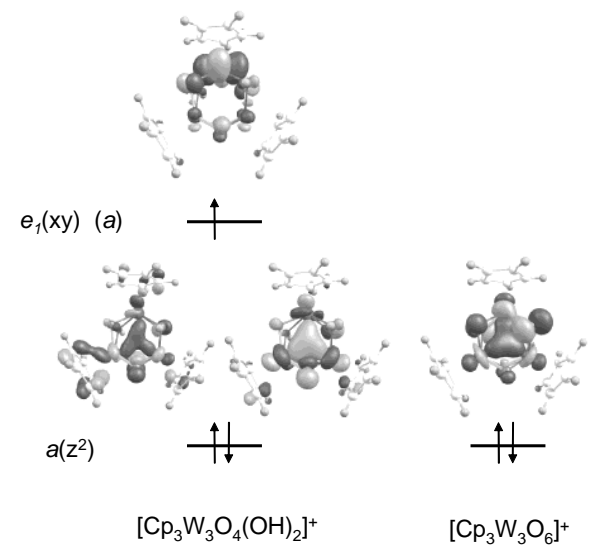

Figure 11. Filled metal-based molecular orbitals for systems 5 (left) and 6 (right). For the former, both spinorbitals resulting from the spin unrestricted calculation are shown. 


\section{(e) Comparison with molybdenum and redox considerations}

The reduction process reported here parallels that reported recently for the reduction of $\mathrm{Cp}_{2}{ }_{2} \mathrm{Mo}_{2} \mathrm{O}_{5}{ }^{[13]}$ However, the Mo system leads to a deeper reduction with generation of a 5-electron cluster, the trinuclear $\mathrm{Mo}_{3}{ }^{\mathrm{IV}, \mathrm{IV}, \mathrm{V}}\left[\mathrm{Cp}^{*}{ }_{3} \mathrm{Mo}_{3} \mathrm{O}_{2}(\mathrm{OH})_{4}\right]^{2+}$ complex. This product has the same molecular architecture as the two trinuclear $\mathrm{W}$ clusters described here, differing only by the number of protons and electrons. This difference agrees with the general trend of greater stability for higher oxidation states upon descending the same group of transition metals. It may be predicted that, by treatment with suitable oxidizing agents (or at a suitable electrochemical potential in an electrochemical experiment) the 5-electron Mo cluster could produce a 3-electron or a 2-electron cluster with the same structure found in the present study for the $\mathrm{W}$ system. Conversely, suitable reductive treatment of the W system could afford a 5-electron system such as the previously reported Mo cluster. Other electronic configurations, e.g. 4-electron $\mathrm{M}^{\mathrm{IV}, \mathrm{V}, \mathrm{V}}$, could also exist. Given that proton gains/losses are associated with these transformations (at least that between the two types of $\mathrm{W}$ clusters reported in the present contribution), it may also be expected that the redox potential is $\mathrm{pH}$-dependent in a protic environment. A detailed analysis of the electrochemical behaviour of these clusters is beyond the scope of the present investigation and may be carried out at a later time.

Previous studies of the $\mathrm{Cp}_{2}{ }_{2} \mathrm{Mo}_{2} \mathrm{O}_{5}$ system by a coupled electrochemical-electrospray mass spectrometry methodology, using a flow-through electrochemical cell, ${ }^{[19,20]}$ revealed a very rich redox behaviour, including the formation of trinuclear clusters that are related to the isolated cluster. We have now attempted to carry out a similar investigation for $\mathrm{Cp}^{*} \mathrm{~W}_{2} \mathrm{O}_{5}$, but no sufficient quantities of soluble products were revealed by the mass spectrometric analysis. At the potential at which the Mo system started to yield reductive processes, the $\mathrm{W}$ system showed no activity, whereas the rapid formation of a film on the surface of the electrode, which blocked any further electrochemical transformation, was observed at lower potentials. Therefore, it seems that the $\mathrm{Cp}^{*}{ }_{2} \mathrm{~W}_{2} \mathrm{O}_{5}$ is more difficult to reduce than the Mo analogue and the primary reduction products (perhaps including the isolated trinuclear clusters described here) are unstable under these highly reducing conditions and proceed further to yield insoluble products.

\section{Conclusions}

Like its Mo analogue, ${ }^{[13]}$ compound $\left[\mathrm{Cp}_{2}{ }_{2} \mathrm{~W}_{2} \mathrm{O}_{5}\right]$ can be reduced in an aqueous medium to a triangular metal-metal bonded cluster. However, only 2- and 3-electron clusters are obtained for W, whereas the Mo system undergoes a deeper reduction, yielding a 5electron cluster. Like for the Mo cluster, the oxo/hydroxo asymmetry in the bridge system splits the degeneracy of the " $e$ "type frontier orbitals, as indicated by the EPR spectrum of the 3electron cluster and confirmed by the DFT calculations. The variability of the cluster electrons for this system will be further explored for applications in organometallic chemistry and catalysis.

\section{Experimental Section}

General procedures. All preparations and manipulations were carried out with Schlenk techniques under an oxygen-free argon atmosphere. All glassware was oven-dried at $120^{\circ} \mathrm{C}$. Solvents were dried by standard procedures and distilled under dinitrogen prior to use. ${ }^{1} \mathrm{H}$ NMR spectra were recorded on a Bruker AM 250, operating at $250 \mathrm{MHz}$. Chemical shifts are expressed in ppm downfield from $\mathrm{Me}_{4} \mathrm{Si}$. Coupling constants are given in Hertz. Mass spectra were recorded with a Finnigan (San Francisco, USA) LCQ quadrupole ion-trap mass spectrometer equipped with an electrosprayionization (ESI) interface. The ESI was operated in the positive ion mode with a spray voltage of $4.5 \mathrm{kV}$. The capillary voltage was $20 \mathrm{~V}$ and the source temperature was $100^{\circ} \mathrm{C}$. Mass spectra were obtained by scanning the mass analyzer from $\mathrm{m} / \mathrm{z} 100$ to 2000 with 5 total microscans. Maximum inject time was $400 \mathrm{~ms}$. The analyzer was operated at a background pressure of $2 \cdot 10^{-5}$ Torr. In all experiments, helium was introduced at an estimated pressure of 1 mTorr to improve the ion trapping efficiency and as collision gas for the collision-induced dissociation events. The compounds were isolated in the ion trap with an isolation width of $12 \mathrm{~m} / \mathrm{z}$ units and activated by using increased collision energy to obtain collision-energydissociation profiles. EPR measurements were carried out at the X-band microwave frequency on a Bruker ESP300 spectrometer. The spectrometer frequency was calibrated with diphenylpicrylhydrazyl (DPPH, $g=2.0037$ ). The starting compound, $\left[\mathrm{Cp}_{2}{ }_{2} \mathrm{~W}_{2} \mathrm{O}_{5}\right]$, was prepared as described in the literature. ${ }^{[14]}$

Synthesis and crystallization of $\left[\mathrm{Cp}_{3}{ }_{3} \mathrm{~W}_{3} \mathrm{O}_{4}(\mathrm{OH})_{2}\right]\left(\mathrm{CF}_{3} \mathrm{SO}_{3}\right)_{2} \cdot 2 \mathrm{H}_{2} \mathrm{O}, 1$. Metallic zinc (20 mesh, $0.415 \mathrm{~g}, 6.34 \mathrm{mmol}$ ) was added to a solution of $\left[\mathrm{Cp}_{2}{ }_{2} \mathrm{~W}_{2} \mathrm{O}_{5}\right](50 \mathrm{mg}, 0.070 \mathrm{mmol})$ in $6 \mathrm{~mL}$ of $\mathrm{MeOH}-\mathrm{H}_{2} \mathrm{O}(1: 1 \mathrm{v} / \mathrm{v})$. The mixture was acidified with 10 drops of $\mathrm{CF}_{3} \mathrm{SO}_{3} \mathrm{H}$ and stirred under argon at room temperature for three days, during which time it changed from a yellow solution to a green suspension. The mixture was filtered and the solid was extracted with THF $(0.5 \mathrm{~mL})$. Addition of $1.5 \mathrm{~mL}$ of $\mathrm{Et}_{2} \mathrm{O}$ to the filtrate yielded the product as a green precipitate $(0.047 \mathrm{~g}, 72 \%)$. A single crystal for the X-ray analysis was obtained by diffusion of an $\mathrm{Et}_{2} \mathrm{O}$ layer into a THF solution at room temperature. EPR (X-band, $\left.\mathrm{CH}_{2} \mathrm{Cl}_{2}, 120 \mathrm{~K}\right)$ : $\mathrm{g} \perp$ $=1.89 ; \mathrm{g}_{\|}=1.72\left(\mathrm{a}_{\mathrm{W} \|}=114 \mathrm{G}\right)$.

Synthesis and crystallization of $\left[\mathrm{Cp}_{3}{ }_{3} \mathrm{~W}_{3} \mathrm{O}_{6}\right]\left(\mathrm{CF}_{3} \mathrm{SO}_{3}\right), 2$. A sample of compound 1 (61 mg, $0.044 \mathrm{mmol}$ ) was dissolved in $\mathrm{CH}_{2} \mathrm{Cl}_{2}$ and stirred for $1 \mathrm{~h}$ at room temperature in open air. The color of the green solution turned orange. Evaporation to dryness left an orange power, which was recrystallized from $\mathrm{CH}_{2} \mathrm{Cl}_{2} /$ pentane to give red crystals ( $25 \mathrm{mg}, 47 \%$ yield). ${ }^{1} \mathrm{H} \mathrm{NMR}\left(\mathrm{CDCl}_{3}\right): \delta 2.28$.

Reduction of $\left[\mathrm{Cp}^{*}{ }_{2} \mathrm{~W}_{2} \mathrm{O}_{5}\right]$ by zinc in the presence of $\mathrm{CF}_{3} \mathrm{COOH}$. Formation of compounds 3 and 4. Metallic zinc (20 mesh, $0.415 \mathrm{~g}, 6.34$ $\mathrm{mmol})$ was added to a solution of $\left[\mathrm{Cp}^{*}{ }_{2} \mathrm{~W}_{2} \mathrm{O}_{5}\right](50 \mathrm{mg}, 0.070 \mathrm{mmol})$ in 6 $\mathrm{mL}$ of $\mathrm{MeOH}-\mathrm{H}_{2} \mathrm{O}(1: 1 \mathrm{v} / \mathrm{v})$. The mixture was acidified with 10 drops of $\mathrm{CF}_{3} \mathrm{COOH}$ and stirred under argon at room temperature for five days, during which time it changed from a yellow solution to a green suspension. The mixture was filtered and the solid was dried under vacuum $(31 \mathrm{mg})$. Attempts to produce single crystals from this material failed, only giving powdery precipitates. Red single crystals of compound $\mathbf{3}$ were eventually obtained from $\mathrm{CH}_{2} \mathrm{Cl}_{2}$ /hexane, after exposure of the solution to air. ${ }^{1} \mathrm{H}$ NMR $\left(\mathrm{CD}_{2} \mathrm{Cl}_{2}\right): \delta 2.26$.

In a parallel identical procedure, from one of the numerous attempts to crystallize the green solid, the yellow mother solution of the green powdery precipitate was recovered, dried, and the yellow-orange residue was set again for crystallization from $\mathrm{THF} /$ hexane, yielding single crystals of compound 4. ${ }^{1} \mathrm{H}$ NMR $\left(\mathrm{CDCl}_{3}\right): \delta 2.28$. MS $\left(\mathrm{ESI}, \mathrm{CH}_{2} \mathrm{Cl}_{2}\right)$ : envelope at $\mathrm{m} / \mathrm{z}=1053, \mathrm{M}^{+}$(see Results and Discussion section)

X-ray diffraction studies. A single crystal of each compound was mounted under inert perfluoropolyether at the tip of a glass fibre and cooled in the cryostream of an Oxford-Diffraction XCALIBUR CCD diffractometer. Data were collected using the monochromatic MoKo radiation $(\lambda=0.71073)$. The structures were solved by direct methods $\left(\right.$ SIR97) ${ }^{[21]}$ and refined by least-squares procedures on $F^{2}$ using SHELXL97. ${ }^{[22]}$ All $\mathrm{H}$ atoms attached to carbon were introduced at idealised positions and treated with the riding model. All $\mathrm{H}$ atoms attached to oxygen were either located on difference Fourier syntheses or their coordinates were calculated on the basis of hydrogen bonding geometry and energy considerations. ${ }^{[23]}$ They were then treated as riding on their parent $\mathrm{O}$ atoms 
In compound $\mathrm{Cp}_{3}{ }_{3} \mathrm{~W}_{3} \mathrm{O}_{6}\left(\mathrm{CF}_{3} \mathrm{SO}_{3}\right)$, the cation, $\mathrm{Cp}_{3}{ }_{3} \mathrm{~W}_{3} \mathrm{O}_{6}$, is arranged around a twofold axis resulting in one of the $\mathrm{Cp}^{*}$ to be disordered over two positions. The $\mathrm{CF}_{3} \mathrm{SO}_{3}$ anion is also disordered and arranged around another twofold axis. For both the disordered parts, the atomic positions and anisotropic thermal parameters were restrained to reasonable values using the tools available within SHELXL-97. ${ }^{[2]}$ The drawing of the molecules was realised with the help of ORTEP3. ${ }^{[24]}$ Crystal data and refinement parameters are shown in Table 4. CCDC-643997 - 644000 contain the supplementary crystallographic data for this paper. These data can be obtained free of charge from the Cambridge Crystallographic Data Centre via www.ccdc.cam.ac.uk/data_request/cif.

Computational details. The DFT calculations were carried out on model systems where the $\mathrm{Cp}^{*}$ ligands were replaced on the simpler $\mathrm{Cp}$ rings. The starting geometries were based on the crystallographically determined structures and no symmetry restrictions were imposed. The geometries were fully optimized and the resulting minima of the potential energy surface (PES) were verified by the positive value of all second derivatives of the energy. The calculations were performed using the B3LYP threeparameter hybrid density functional method of Becke ${ }^{[25]}$ and the standard LANL2DZ basis set, which included the Hay and Wadt effective core potentials (ECP) for the tungsten atoms, ${ }^{[26]}$ as implemented in the Gaussian03 suite of programs. ${ }^{[27]}$ The calculation on the open-shell system 5 was carried out using the spin-unrestricted formulation. The value of $\left\langle\mathrm{S}^{2}\right\rangle$ resulting from the calculation is 0.7575 , indicating negligible spin contamination.

Supporting Information (see footnote on the first page of this article): Packing diagrams for compounds 3 and 4; energy diagrams and representative molecular orbitals for systems $\mathbf{5}$ and $\mathbf{6}$ (5 pages).

\section{Acknowledgments}

We are grateful to the European Commission for funding of this work through the AQUACHEM Research Training Network (Project ${ }^{\circ}$ MRTNCT-2003-503864). We also thank CINES and CICT (project CALMIP) for a grant of free computer time. Supplemental travel support was provided by a Bosphorus bilateral Program of Integrated Actions, co-sponsored by the French Ministry of Foreign Affairs in France and by TUBITAK in Turkey (TBAG-U/142(105T256)).

[1] T. Chan, L. Li, Y. Yang, W. Lu, ACS Symp. Ser. 2002, 819, 166-177.

[2] F. Joó, Acc. Chem. Res. 2002, 35, 738-745.

[3] I. T. Horvath, Acc. Chem. Res. 2002, 35, 685.

[4] D. Sinou, Topics Curr. Chem. 1999, 206, 41-59.

[5] D. Sinou, Adv. Synth. Catal. 2002, 344, 221-237.

[6] G. E. Jaouen, J. Organometal. Chem. (special issue: bioorganometallic chemistry) 1999, 589.

[7] P. Kalck, F. Monteil, Adv. Organometal. Chem. 1992, 34, 219-284.

[8] B. E. Hanson, Coord. Chem. Rev. 1999, 186, 795-807.

[9] C. Muller, D. Vos, P. Jutzi, J. Organometal. Chem. 2000, 600, 127-143.

[10] A. Bino, F. A. Cotton, Z. Dori, J. Am. Chem. Soc. 1981, 103, 243-244.

[11] A. Bino, M. Ardon, E. Shirman, Science 2005, 308, 234235.

[12] R. Poli, Chem. Eur. J. 2004, 10, 332-341.

[13] F. Demirhan, B. Çagatay, D. Demir, M. Baya, J.-C. Daran, R. Poli, Eur. J. Inorg. Chem. 2006, 757-764.
[14] C. Dinoi, G. Taban, P. Sözen, F. Demirhan, J.-C. Daran, R. Poli, J. Organomet. Chem. in press.

[15] A. L. Grzesiak, F. J. Uribe, N. W. Ockwig, O. M. Yaghi, A. J. Matzger, Angew. Chem., Int. Ed. Engl. 2006, 45, 2553-2556.

[16] J. S. Seo, D. Whang, H. Lee, S. I. Jun, J. Oh, Y. J. Jeon, K. Kim, Nature 2000, 404, 982-986.

[17] P. Kubácek, R. Hoffmann, Z. Havlas, Organometallics 1982, 1, 180-188.

[18] T. A. Albright, J. K. Burdett, M. H. Whangbo, Orbital Interactions in Chemistry, J. Wiley \& Sons, New York, 1985.

[19] J. Gun, A. Modestov, O. Lev, D. Saurenz, M. A. Vorotyntsev, R. Poli, Eur. J. Inorg. Chem. 2003, 482-492.

[20] J. Gun, A. Modestov, O. Lev, R. Poli, Eur. J. Inorg. Chem. 2003, 2264-2272.

[21] A. Altomare, M. Burla, M. Camalli, G. Cascarano, C. Giacovazzo, A. Guagliardi, A. Moliterni, G. Polidori, R. Spagna, J. Appl. Cryst. 1999, 32, 115-119.

[22] G. M. Sheldrick, SHELXL97. Program for Crystal Structure refinement, University of Göttingen, Göttingen, Germany, 1997.

[23] M. Nardelli, J. Appl. Cryst. 1999, 32, 563-571.

[24] L. J. Farrugia, J. Appl. Crystallogr. 1997, 32, 565.

[25] A. D. Becke, J. Chem. Phys. 1993, 98, 5648-5652.

[26] P. J. Hay, W. R. Wadt, J. Chem. Phys. 1985, 82, 270-283.

[27] M. J. Frisch, G. W. Trucks, H. B. Schlegel, G. E. Scuseria, M. A. Robb, J. R. Cheeseman, J. Montgomery, J. A., T. Vreven, K. N. Kudin, J. C. Burant, J. M. Millam, S. S. Iyengar, J. Tomasi, V. Barone, B. Mennucci, M. Cossi, G. Scalmani, N. Rega, G. A. Petersson, H. Nakatsuji, M. Hada, M. Ehara, K. Toyota, R. Fukuda, J. Hasegawa, M. Ishida, T. Nakajima, Y. Honda, O. Kitao, H. Nakai, M. Klene, X. Li, J. E. Knox, H. P. Hratchian, J. B. Cross, C. Adamo, J. Jaramillo, R. Gomperts, R. E. Stratmann, O. Yazyev, A. J. Austin, R. Cammi, C. Pomelli, J. W. Ochterski, P. Y. Ayala, K. Morokuma, G. A. Voth, P. Salvador, J. J. Dannenberg, V. G. Zakrzewski, S. Dapprich, A. D. Daniels, M. C. Strain, O. Farkas, D. K. Malick, A. D. Rabuck, K. Raghavachari, J. B. Foresman, J. V. Ortiz, Q. Cui, A. G. Baboul, S. Clifford, J. Cioslowski, B. B. Stefanov, G. Liu, A. Liashenko, P. Piskorz, I. Komaromi, R. L. Martin, D. J. Fox, T. Keith, M. A. Al-Laham, C. Y. Peng, A. Nanayakkara, M. Challacombe, P. M. W. Gill, B. Johnson, W. Chen, M. W. Wong, C. Gonzalez, J. A. Pople, Gaussian 03, Revision B.04, Gaussian, Inc., Pittsburgh PA, 2003.

Received: ((will be filled in by the editorial staff)) Published online: ((will be filled in by the editorial staff)) 
Table 4. Selected crystallographic and refinement parameters for all compounds.

\begin{tabular}{|c|c|c|c|c|}
\hline Compound & 1 & 2 & 3 & 4 \\
\hline Empirical formula & $\mathrm{C}_{32} \mathrm{H}_{49} \mathrm{~F}_{6} \mathrm{O}_{14} \mathrm{~S}_{2} \mathrm{~W}_{3}$ & $\mathrm{C}_{31} \mathrm{H}_{45} \mathrm{~F}_{3} \mathrm{O}_{9} \mathrm{~S} \mathrm{~W}_{3}$ & $\mathrm{C}_{44} \mathrm{H}_{53} \mathrm{~F}_{21} \mathrm{O}_{24} \mathrm{~W}_{3} \mathrm{Zn}_{3}$ & $\mathrm{C}_{36} \mathrm{H}_{53} \mathrm{~F}_{9} \mathrm{O}_{17} \mathrm{~W}_{3} \mathrm{Zn}_{0.5}$ \\
\hline Formula weight & 1387.38 & 1202.28 & 2112.52 & 1513.02 \\
\hline Temperature & $180(2) \mathrm{K}$ & $180(2) \mathrm{K}$ & $180(2) \mathrm{K}$ & $180(2) \mathrm{K}$ \\
\hline Wavelength & $0.71073 \AA$ & $0.71073 \AA$ & $0.71073 \AA$ & $0.71073 \AA$ \\
\hline Crystal system & Monoclinic & Monoclinic & Monoclinic & Triclinic \\
\hline Space group & $\mathrm{P} 2{ }_{1} / \mathrm{a}$ & $\mathrm{C} 2 / \mathrm{c}$ & $\mathrm{C} \mathrm{c}$ & $\mathrm{P}-1$ \\
\hline $\mathrm{a}, \AA$ & $19.6490(7)$ & $16.7981(11)$ & $12.9884(12)$ & $12.8993(12)$ \\
\hline $\mathrm{b}, \AA$ & $11.1968(4)$ & $15.1424(7)$ & $21.8922(15)$ & $13.2879(13) \AA$ \\
\hline c, $\AA$ & $19.7744(8)$ & $14.9343(8)$ & $22.862(2)$ & $16.6848(18) \AA$ \\
\hline$\alpha,^{\circ}$ & 90 & 90 & 90 & $96.016(8)$ \\
\hline$\beta,^{\circ}$ & $106.433(3)$ & $113.172(5)$ & $90.493(7)$ & $104.993(9)$ \\
\hline$\gamma,{ }^{\circ}$ & 90 & 90 & 90 & $116.737(9)$ \\
\hline Volume, $\AA^{3}$ & $4172.8(3)$ & $3492.3(3)$ & $6500.5(9)$ & $2384.7(4)$ \\
\hline $\mathrm{Z}$ & 4 & 4 & 4 & 2 \\
\hline Density (calculated), $\mathrm{Mg} / \mathrm{m}^{3}$ & 2.208 & 2.287 & 2.159 & 2.107 \\
\hline Absorption coefficient, $\mathrm{mm}^{-1}$ & 8.438 & 9.984 & 6.509 & 7.564 \\
\hline $\mathrm{F}(000)$ & 2644 & 2272 & 4040 & 1446 \\
\hline Crystal size, $\mathrm{mm}^{3}$ & $0.27 \times 0.14 \times 0.09$ & $0.26 \times 0.205 \times 0.043$ & $0.32 \times 0.2 \times 0.126$ & $0.34 \times 0.15 \times 0.034$ \\
\hline$\theta$ range, ${ }^{\circ}$ & 2.79 to 26.37 & 3.65 to 30.03 & 3.20 to 28.28 & 2.61 to 25.03 \\
\hline $\mathrm{h}, \mathrm{k}, 1$ ranges & $-24 \div 24,-13 \div 13,-23 \div 24$ & $-23 \div 16,-21 \div 21,-19 \div 21$ & $-16 \div 17,-29 \div 29,-30 \div 29$ & $-15 \div 15,-15 \div 14,-19 \div 18$ \\
\hline Reflections collected & 29412 & 17199 & 28767 & 14697 \\
\hline Independent reflections & $8524[\mathrm{R}(\mathrm{int})=0.0348]$ & $5088[\mathrm{R}$ (int) $=0.0369]$ & $11663[\mathrm{R}(\mathrm{int})=0.0547]$ & $8107[\mathrm{R}(\mathrm{int})=0.0691]$ \\
\hline Completeness to $\theta=25.00^{\circ}, \%$ & 99.8 & 99.7 & 99.9 & 96.3 \\
\hline Absorption correction & Multi-scan & Multi-scan & Multi-scan & Multi-scan \\
\hline Max. and min. transmission & 0.3589 and 0.1896 & 0.3236 and 0.1509 & 1.0 and 0.2368 & \\
\hline Refinement method & Full-matr. least-sq. $\left(\mathrm{F}^{2}\right)$ & Full-matr. least-sq. $\left(\mathrm{F}^{2}\right)$ & Full-matr. least-sq. $\left(\mathrm{F}^{2}\right)$ & Full-matr. least-sq. $\left(\mathrm{F}^{2}\right)$ \\
\hline Data / restraints / parameters & $8524 / 8 / 547$ & $5088 / 32 / 226$ & 11663 / 32 / 857 & $8107 / 0 / 436$ \\
\hline Goodness-of-fit on $\mathrm{F}^{2}$ & 1.124 & 1.182 & 0.923 & 0.867 \\
\hline $\mathrm{R} 1, w \mathrm{w} 2[\mathrm{I}>2 \sigma(\mathrm{I})]$ & $0.0324,0.0738$ & $0.0417,0.0883$ & $0.0382,0.0619$ & $0.0502,0.0921$ \\
\hline R1, wR2 (all data) & $0.0413,0.0772$ & $0.0484,0.0909$ & $0.0502,0.0649$ & $0.1356,0.1097$ \\
\hline Absolute structure parameter & & & $0.007(6)$ & \\
\hline Largest diff. peak and hole, $\mathrm{e} \cdot \AA^{-3}$ & 3.747 and -1.748 & 2.455 and -3.030 & 1.489 and -1.302 & 4.859 and -1.751 \\
\hline
\end{tabular}




\section{Entry for the Table of Contents}

Aqueous reduction of $\left[\mathrm{Cp}_{2} \mathrm{~W}_{2} \mathrm{O}_{5}\right]$

Two related triangular tungsten clusters, the 3-electron

$\left[\mathrm{Cp}_{3}{ }_{3} \mathrm{~W}_{3} \mathrm{O}_{4}(\mathrm{OH})_{2}\right]^{2+}$ and the 2-electron $\left[\mathrm{Cp}_{3} \mathrm{~W}_{3} \mathrm{O}_{6}\right]^{+}$, obtained by aqueous reduction of $\left[\mathrm{Cp}_{2}{ }_{2} \mathrm{~W}_{2} \mathrm{O}_{5}\right]$, are described.
Chiara Dinoi, Pelin Sözen, Gülnur

Taban, Deniz Demir, Funda

Demirhan,* Petr Prikhodchenko, Jenny Gun, Ovadia Lev, Jean-Claude Daran and Rinaldo Poli* Page No. - Page No.

Aqueous chemistry of $\left[\mathrm{Cp}_{2}{ }_{2} \mathrm{~W}_{2} \mathrm{O}_{5}\right]$ : characterization of triangular clusters obtained by zinc reduction. Comparison with molybdenum

Keywords: Tungsten / Aqueous organometallic chemistry / Oxo ligands / Metal clusters / DFT calculations 